\title{
TORT LIABILITY OF GOVERNMENTAL UNITS AND THEIR OFFICERS
}

\author{
FIEMTNG JAMES, JR.†
}

U NDER THE PREVAILING DOCTRINE in this country neither the state nor the federal government is liable for torts committed in its service by its officers and employees unless it consents to such liability; the officer or employee, however, may be individually liable. This removes at once a very substantial area of injury-producing activity from the operation of forces which have tended to make much of our tort law a vehicle for distributing the loss suffered by the victims of enterprise among the beneficiaries of the enterprise. ${ }^{1}$ The expansion of the activities of government during recent decades points up sharply the striking character of this exceptional immunity from liability of one of the best loss-distributing agencies in our society.

Strong pressures have inevitably been at work to push back this immunity, ${ }^{2}$ and these pressures have had measurable success. Further inroads upon the immunity are likely and desirable. Yet the position and functions of government are to a certain extent unique, and we may never want them to be treated altogether like those of private enterprise.

Here we shall examine something of the bases in history, reasoning, and policy of the immunity; sketch its present status in the United States and recent developments in the field; and suggest the possible courses of future development. Inextricably interwoven with all these matters is the question of individual liability of government officers and employees. This, too, will be treated; and something of the interconnection among the problems will be suggested.

+ Professor of Law, Yale Law School.

${ }^{1}$ Consult Gregory, Trespass to Nuisance to Absolute Liability, 37 Va. L. Rev. 359 (1951) ; James, Accident Liability Reconsidered: The Impact of Liability Insurance, 57 Yale L. J. 549 (1948) ; Ehrenzweig, Negligence without Fault (1951).

${ }^{2}$ The scholar whose work spearheaded this pressure was Edwin M. Borchard. A comprehensive critical review of the whole subject matter herein dealt with appears in Borchard, Government Liability in Tort, 34 Yale L. J. 1, 129, 229 (1924-25) ; Governmental Responsibility in Tort, 36 Yale L. J. 1, 757, 1039 (1926-27); 28 Col. L. Rev. 577, 734 (1928). Recognition of Borchard's role may be seen in Repko, American Legal Commentary on the Doctrines of Municipal Tort Liability, 9 Law \& Contemp. Prob. 214 (1942). 


\section{Bases in History, Reasoning, and Policy}

1. History. Whether governmental immunity had roots in Roman law is a question that need not detain us here. ${ }^{3}$ American notions were largely the product of English developments which trace back to the position of the king in medieval times, and then to his identification with the concept of "sovereignty" which arose during the sixteenth and seventeenth centuries. ${ }^{4}$ At least from the time of Edward I, the king was not suable in his own courts as a matter of right." This was not the result of any metaphysical notion of the king's "sovereignty." No feudal lord could be sued of right in his own court. "That the King as chief of the feudal system had no court above him, in which he could be held liable, as the feudal lords could be in his, was the result rather of accident than theory." The king was thought to be human and fallible, and subject to God and the law, but not suable on earth for want of an appropriate temporal court to entertain the suit. It was not until after the breakdown of feudalism that the king became identified with the state and the theory of sovereignty was fashioned to clothe the king-state entity. Here, in the days of the later Tudors and Stuarts in England and of Louis XIII and XIV in France, the days of Bodin and Hobbes, "we are plunged into talk about kings who do not die, who are never under age, who are ubiquitous, who do no wrong and (says Blackstone) think no wrong; and such talk

${ }^{3}$ For more or less divergent views, see Watkins, The State as a Party Litigant 1-4 (1927) (hereafter cited as Watkins) (which tends to minimize the probable effect); 2 Goodnow, Comparative Administrative Law 149, 169 (1893) (suggesting Roman origin); Parker, The King Does No Wrong-Liability for Misadministration, 5 Vand. L. Rev. 167 (1952) (the English maxim "has its counterpart if not origin in the Roman-Byzantine holding, princeps legibus solutus est").

'See Borchard, op. cit. supra note 2, 36 Yale L. J. 1, 30 et seq. (1926); Blachly \& Oatman, Approaches to Government Liability in Tort: A Comparative Study, 9 Law \& Contemp. Prob. 181 (1942) ; Watkins c. 1; 3 Holdsworth, History of English Law 458-69 (5th ed., 1942) ; 4 ibid., 190-217 (3d ed., 1937) (all editions have the same pagination. Cited hereafter as Holdsworth); 1 Pollock \& Maitland, History of English Law 495-511 (1st ed., 1895) (original pagination indicated marginally in 2d ed., reprint 1952. Hereafter cited as Pollock \& Maitland).

5 There were repeated early statements that before the time of Edward I (1272-1307) the king was suable in his own courts. See 1 Pollock \& Maitland 500 (quoting and translating passage from Y.B. Edw. I 471); sources cited Watkins 6 . The evidence is all secondary and modern historians conclude that he probably never was so suable as a matter of right. Borchard, op. cit. supra note 2, 36 Yale L. J. 1, 23 (1926) ; 9 Holdsworth 12; 1 Pollock \& Maitland 500; Watkins 7.

'Watkins 7.

${ }^{7}$ Consult, in general, Borchard, op. cit. supra note 2, 36 Yale L. J. 1-41 (1926); authorities cited note 4 supra. 
has not been innocuous." The ancient maxim that "the King can do no wrong" took on new meaning and came to stand for a notion that the sovereign was incapable of doing wrong. ${ }^{9}$ This was a substantive ground of immunity in addition to the mere lack of a court with power to enforce remedies against the king.

Just how an immunity which had its roots in feudalism and in a political philosophy associated with the divine right of kings was transplanted to the new republic in America remains something of a mystery..$^{10}$ Yet it seems to have been generally applied in favor of both the states and the federal government without much discussion as part of the existing order of things. ${ }^{11}$ To be sure, dissenting voices prevailed on one occasion $;^{12}$ but this was quickly followed by the Eleventh Amendment. ${ }^{13}$ Since then the doctrine that neither a state nor the United States is liable in tort without its consent has been generally accepted.

2. Bases in Reasoning and Policy. In a famous dictum, Mr. Justice Holmes said "[a] sovereign is exempt from suit, not because of any formal conception or obsolete theory, but on the logical and practical ground that there can be no legal right as against the authority that makes the law on which the right depends."14 Of course, those who wield the ultimate political power in a society do have it in their hands to determine whether or not that society shall be under corporate liability to its individual members. But the absence of "legal right"

3 Maitland, Collected Papers 251-52 (1911), quoted in Watkins at 11.

- Borchard, op. cit. supra note 2, 36 Yale L. J. 1, 35 (1926).

${ }^{10}$ Borchard, op. cit. supra note 2, 36 Yale L. J. 1, 4 (1926); Watkins 50; Street, Governmental Liability 8,9 (1953) (hereafter cited as Street); Schwartz, French Administrative Law and the Common Law World 266, 267 (1954) (hereafter cited as Schwartz).

The heavy indebtedness of the states and their precarious financial condition during the years immediately after the Revolution no doubt played a part in this. Watkins 5254. Compare Gellhorn \& Schenck, Tort Actions against the Federal Government, $47 \mathrm{Col}$. L. Rev. 722 (1947). Consult also Schwartz, Public Tort Liability in France, 29 N.Y.U. L. Rev. 1432, 1436 (1954).

11 "While the political theory that the King can do no wrong was repudiated in America, a legal doctrine derived from it that the Crown is immune from any suit to which it has not consented was invoked on behalf of the Republic and applied by our courts as vigorously as it had been on behalf of the Crown." Feres v. United States, 340 U.S. 135, 139 (1950); see also authorities cited note 10 supra.

12 Chisholm v. Georgia, 2 U.S. 419 (1793).

${ }^{13}$ U.S. Const. Amend. 11, ratified in 1798, provides: "The Judicial power of the United States shall not be construed to extend to any suit in law or equity, commenced or prosecuted against one of the United States by Citizens of another State or by Citizens or Subjects of any Foreign State."

"Kawananakoa v. Polyblank, 205 U.S. 349, 353 (1907). 
against the sovereign does not accurately reflect even English history, ${ }^{15}$ for the petition of right against the king has been an institutionalized practice since the reign of Edward $I .{ }^{16}$ And Holmes's dictum offers no help in solving the problem of whether a modern democratic society should, as a matter of either morals or expediency, assume liability and, if so, to what extent. ${ }^{17}$

In addition to this more or less modern and rational version of sovereign immunity, there has kept recurring the older notion that since the sovereign can do no wrong, it cannot authorize a wrong to be done for it, "[for] to authorize a wrong to be done is to do a wrong." ${ }^{\text {18 }}$ It follows that any tort committed by an officer or employee of the sovereign is ultra vires, so that the sovereign can never be liable under the doctrine of respondeat superior, which amounts to saying that it can never be liable. This reasoning, which is parallel to earlier and discredited notions about the vicarious liability of corporations, ${ }^{19}$ has little appeal to the mind of today and little current vogue in America; $;^{20}$ nor does it deserve any. It is highly conceptualistic and involves

${ }^{15}$ Except perhaps in the narrowest Austinian sense. Although relief under the Petition of Right might be characterized by a strict Austinian as "of grace," yet, as Borchard points out, an equally tenable definition of law, which embraces "a regular course of action by societal agents, predictable and sanctioned by popular conviction, departure from which was rare and admittedly evidence of bad faith," would cover the Petition of Right. Borchard, op. cit. supra note 2, 36 Yale L. J. 1, 24 (1926).

${ }^{10}$ While such petitions were regularly granted in certain situations (in early times largely where recovery of real property was sought, later in contract cases), they were regularly denied in others, including most tort situations. Watkins c. 2. Consult also Holdsworth, History of Remedies against the Crown, 38 L. Q. Rev. 141 (1922); Ehrlich, Proceedings against the Crown, 6 Oxford Studies in Social and Legal History '(1921).

17 "Our concern in any controversy between the state and a private person should be, not what the power of the respective litigating parties may be, but with who is right." Anderson, Claims against States, 7 Vand. L. Rev. 234, 245 (1954). The author concludes that the time has come for all governments to waive immunity in tort. Compare Parker, The King Does No Wrong-Liability for Misadministration, 5 Vand. L. Rev. 167, 168 (1952).

Perhaps this is not primarily a judicial problem today though the courts played a large part in bringing the doctrine into the common law. Even if there is to be no general overthrow of immunity as a matter of common-law development, however, courts will play a role in working out exceptions (see, e.g., notes 238-41 infra) and interpreting statutes (see notes 250 and 266 infra).

It is noteworthy that the French system of state liability was worked out largely by the Conseil d'Etat, her administrative court. Schwartz 269-71. And see Wolfe, J., dissenting in Bingham v. Board of Education, 223 P. 2d 432, 438 (Utah, 1950).

${ }^{18}$ Feather v. Regina, 6 Best \& S. 257, 295 (1865).

${ }^{10}$ See Osipoff v. City of New York, 286 N.Y. 422, 36 N.E. 2d 646, 648 (1941); Harper, Law of Torts $\$ 293$ (1933); Borchard, op. cit. supra note 2, 36 Yale L. J. 1, 20 (1926).

${ }^{30}$ See Borchard, op. cit. supra note 2, 34 Yale L. J 1, 20 (1924). 
complete misunderstanding of the basis of vicarious liability. ${ }^{21}$

Governmental immunity has sometimes been defended on grounds of policy. The argument is fourfold: (1) funds devoted to public purposes should not be diverted to compensate for private injuries; ${ }^{22}$ (2) "the public service would be hindered, and the public safety endangered, if the superior authority could be subjected to suit at the instance of every citizen, and, consequently, controlled in the use and disposition of the means required for the proper administration of the Government"; ${ }^{23}$ (3) that liability would involve the government "in all its operations, in endless embarrassments, and difficulties, and losses, which would be subversive of the public interests"; ${ }^{24}$ and (4) that unlike private enterprise, the government derives no profit from its activities. ${ }^{25}$ To these arguments it may be answered in part (1) that since the public purposes involve injury-producing activity, the injuries thus caused should be viewed as a part of the activity's normal costs, and no one suggests that it is a diversion of public funds to pay the costs of public enterprise even if payment is made to private persons; (2) that while control of government activity by private tort litigation may be involved where the alleged tort is legislative action or the making of some high-level policy decision, no such thing is involved in ordinary accident cases; (3) that the direct cost of making compensation by the government will not exceed the sum of the losses suffered by the hapless victims of government activity, and that it is better to distribute these losses widely among the beneficiaries of government than to let them rest on the individual victims; that the embarrassments and expenses incidental to defending accident suits are also a part of the just social cost of operations that cause injuries and have never stifled comparable private enterprise; and finally (4) that, though the government as an entity does not profit from its enterprises,

${ }^{21}$ Consult, e.g., Laski, Basis of Vicarious Liability, 26 Yale L. J. 105 (1916) ; Smith, Frolic and Detour, 23 Col. L. Rev. 444, 716 (1923); Douglas, Vicarious Liability and Administration of Risk, 38 Yale L. J. 584, 720 (1929); James, Vicarious Liability, 28 Tulane L. Rev. 161 (1954).

${ }^{22}$ Repko, American Legal Commentary on the Doctrines of Municipal Tort Liability, 9 Law \& Contemp. Prob. 214, 220 (1942); Note, 33 Minn. L. Rev. 634, 636 (1949). Compare Fuller \& Casner, Municipal Tort Liability in Operation, 54 Harv. L. Rev. 437, 440 (1941).

${ }^{23}$ Field, J., in The Siren, 74 U.S. 152, 154 (1868); Watkins 56.

${ }^{24}$ Murdock Parlor Grate Co. v. Commonwealth, 152 Mass. 28, 32, 24 N.E. 854, 856 (1890), quoting Story on Agency $\S 319$ (9th ed., 1882).

${ }^{25}$ Smith, Municipal Tort Liability, 48 Mich. L. Rev. 41, 51 (1949); 38 Am. Jur., Municipal Corporations $\$ 575$ (1941). 
yet (it is devoutly to be hoped) the taxpaying public does, and it is the taxpaying public which would bear the costs of government tort liability.

Few, if any, scholars and commentators could be found today to defend the full extent of governmental immunity.$^{26}$ On the other hand, no one today urges that a judicial remedy be given for all the injuries that may result from mistaken governmental action, or that the courts should decide when governmental action of a political nature is mistaken. ${ }^{27}$ The proper sphere of governmental immunity will remain a vital question even under systems which relax the indefensibly broad immunity which still prevails in most of our states. Before we reach an analysis of this problem, however, we should examine the prevailing rules.

\section{TORT Liability of Governmental UNits}

1. The State. So far as the general rule goes, little can be added to what has been said. The state without its consent is not liable for the torts of its agents, officers, and employees even though they are acting in its service at the time the tort is committed. Questions naturally arise, however, as to how it may consent and whether the rule has exceptions.

The state may consent to liability by statute..$^{28}$ This seems not to be

${ }^{28}$ Consult, e.g., Borchard, op. cit. supra note 2, 36 Yale L. J. 757, 802 et seq., 1039, 1097, et seq. (1927) ; Borchard, Government Responsibility in Tort-A Proposed Statutory Reform, 11 A.B.A.J. 495 (1925); Symposium on Government Tort Liability, 9 Law \& Contemp. Prob. 179 (1942); Gellhorn \& Schenck, Tort Actions against the Federal Government, 47 Col. L. Rev. 722 (1947) ; Schwartz 302; Street 185; Watkins c. 12.

Cf. Frankfurter, J., dissenting in Great Northern Ins. Co. v. Read, 322 U.S. 47,59 (1944), and in Snyder v. Buck, 340 U.S. 15, 29 (1950); Carter, J., dissenting in Madison v. City and County of San Francisco, 106 Calif. App. 232, 236 P. 2d 141 (1951); Wolfe, J., dissenting in Bingham v. Board of Ed., 118 Utah 582, 593, 223 P. 2d 432, 438 (1950).

${ }^{2}$ Consult, e.g., Borchard, op. cit. supra note 2, 34 Yale L. J. 1 (1924); Gellhorn and Schenck, op. cit. supra note 26 at 739 ; Smith, op. cit. supra note 25 at 52 ; Schwartz 298-302 (pointing out, however, that the French law recently has allowed recovery in such cases under some circumstances, but suggesting that the notion is "an indirect way to accomplish what the American courts can do directly through their authority to declare statutes unconstitutional"). Compare Street 74 ("Most French jurists would support the continuance of actes de gouvernemrent" for which the state is not liable "in a restricted form on the ground that it is a necessary condition of harmony between the Administration and the Judiciary").

${ }^{23}$ And of course by constitutional provision. Compare note 43 infra.

The statement in the text must be qualified for the four states which have constitutional provisions to the effect that the state shall not be a defendant in their courts. Ala. Const. Art. I, $\S 14$; Ark. Const. Art. V, $\S 20$; III. Const. Art. IV, $\S 26$; W. Va. Const. Art. VI, $\$ 35$ (except as garnishee). Compare, however, authorities cited note 230 infra. 
doubted, ${ }^{29}$ at least where the statute is general, outlining for the future the conditions of liability. Where an injury has already been done, the American practice has been to seek relief by private act of the legislature; and such bills have often been enacted, ${ }^{30}$ although such an enactment, on occasion, has been held unconstitutional. ${ }^{31}$ Only the legislature, or the authority that may make or alter the constitution, may give effective consent to a suit against the state. Neither an executive board $^{32}$ nor the attorney general ${ }^{33}$ may do so unless authorized by a statute or constitutional provision. ${ }^{34}$

Some fairly recent cases have raised the question whether the purchase of liability insurance by a governmental body constitutes a waiver of its immunity. Most of them have decided that it does not, at least in the absence of statutory authority to purchase the insurance. ${ }^{35}$ Some cases have exonerated the governmental unit even in the face of

${ }^{2}$ Benson v. State Hospital Comm'n, 316 Mich. 66, 25 N.W. 2d 112 (1946); Ouzts v. State Hwy. Dep't, 161 S.C. 21, 159 S.E. 457 (1931).

${ }^{20}$ Private acts are of two kinds: legislation divesting the state of immunity and allowing suit in a specific case, and appropriations for the relief -of individuals. See Sandel v. State, 115 S.C. 168, 104 S.E. 567 (1920) (but consult cases cited note 31 infra); Nutting, Legislative Practice regarding Tort Claims against the State, 4 Mo. L. Rev. 1 (1939); Shumate, Tort Claims against State Governments, 9 Law \& Contemp. Prob. 242, 249 (1942); Claims against the State in Minnesota, 32 Minn. L. Rev. 539 (1948); note, 13 A.L.R. 1276, 1280-81 (1921).

${ }^{31}$ Cox v. State, 134 Neb. 751, 279 N.W. 482 (1938) (enactment of special law where general one could have been applicable); Vigil v. State, 56 N.M. 411, 244 P. 2d 1110 (1952) (same); Sirrine v. State, 132 S.C. 241, 128 S.E. 172 (1925) (same; also equal protection of laws clause violated), overruling Sandel v. State, 115 S.C. 168, 104 S.E. 567 (1920). Cf. Green v. State, 73 Calif. 29, 14 Pac. 610 (1887) (claim that such legislation an improper "gift" noted, but not passed on).

The above rulings of unconstitutionality all concerned special acts allowing individual suit. Special appropriation acts are "the most prevalent and most objectionable means of dealing with the problem," and rarely succumb to constitutional challenge. Nutting, op. cit. supra note 30 at 16,17 .

${ }^{32}$ Farish v. State Banking Bd., 235 U.S. 498 (1915); Metropolitan Tr. Co. v. State Bd, of Tax Comm'rs, 220 N.Y. 344, 115 N.E. 1000 (1917) ; Lankford v. Schroeder, 47 Okla. 279, 147 Pac. 1049 (1915).

${ }^{33}$ Bow v. Plummer, 79 N.H. 23, 104 AtI. 35 (1918); Morrah v. Dr. John De La Howe Ind. School, 120 S.C. 197, 113 S.E. 70 (1922) (state may "be sued only by permission granted; that permission can be granted only by the General Assembly. . . . The Attorney General ... has not the power to ... consent to such suit").

${ }^{34}$ E.g., Gunter v. Atlantic C.L.R.R., 200 U.S. 273 (1906); McKeown v. Brown, 167 Iowa 489, 149 N.W. 593 (1914).

${ }^{35}$ Ritmiller v. School Dist. No. 84, 104 F. Supp. 187 (D. Minn., 1952); Hummer v. School City of Hartford City, _- Ind. —, 112 N.E. 2d 891 (1953); Stephenson v. Raleigh, 232 N.C. 42, 59 S.E. 2d 195 (1950); Kesman v. Fallowfield Township School Dist., 345 Pa. 457, 29 A. 2d 17 (1942); Boice v. Board of Education, 111 W. Va. 95, 160 S.E. 566 (1931); note, 33 Minn. L. Rev. 634 (1949); note, 52 Mich. L. Rev. 457 (1954); James and Thornton, Impact of Insurance on the Law of Torts, 15 Law \& Contemp. 
such authorization..$^{36}$ Where the policy itself stipulates a waiver of immunity, ${ }^{37}$ such a result is shocking indeed.

In the absence of statute or a constitutional provision there is grave. doubt whether the state is liable either for the tortious destruction ${ }^{38}$ or appropriation ${ }^{39}$ of property, or for the creation or maintenance of

Prob. 431, 438 (1950); note, 145 A.l.R. 1336 (1943). Cf. Lambert v. New Haven, 129 Conn. 647, 30 A. 2d 923 (1943). But see Bailey v. City of Knoxville, 113 F. Supp. 3 (E.D. Tenn., 1953).

${ }^{30}$ Pohland v. Sheboygan, 251 Wis. 20, 27 N.W. 2d 736 (1947).

${ }^{37}$ As it did in the Pohland case. Two types of contracts are written on governmental risks. One is written at a premium substantially lower than that for private organizations just because of the immunity. The other is written at a regular premium rate with an endorsement providing that the insurer will not avail himself of the defense of immunity. See note, 33 Minn. L. Rev. 634, 643 (1949). Where there is such a provision and statutory authority to buy insurance, recovery should be allowed, as it was in Taylor v. Knox County Bd. of Ed., $292 \mathrm{Ky} .767,167$ S.W. 2d 700 (1942). Consult also Rogers v. Butler, 170 Tenn. 125, 92 S.W. 2d 414 (1936) (terms of policy do not appear).

${ }^{38}$ Hughes v. United States, 230 U.S. 24 (1913) (damage resulting from wrongful use of dynamite in flood emergency); People v. Buellton Development Co., 58 Calif. App. 2d 178, 136 P. 2d 793 (1943) (wrongful tearing down of fences by state highway department officials); 6 Nichols, Eminent Domain 451 (3d ed., 1953) (hereafter cited as Nichols).

If plaintiff's property is destroyed by the sporadic negligence of persons carrying out a public project, the state is not liable.

There are cases bolding a municipality liable where it has authorized or ratified acts done by its officers which tortiously injure plaintiff. The leading case is Thayer v. Boston, 36 Mass. 511 (1837) (obstruction of highway). Other examples are Langley v. Augusta, 118 Ga. 590, 45 S.E. 486 (1903) (maintenance of drain and sewers so as to back up water); Willson v. Boise, 20 Idaho 133, 117 Pac. 115 (1911) (allowing diverted stream to resume former course); Barrows v. Sycamore, 150 IIl. 588, 37 N.E. 1096 (1894) (building water tower in highway); Persons v. Valley City, 26 N.D. 342, 144 N.W. 675 (1913) (similar to Buellton case, city road).

Some courts have imposed liability on counties or school districts on the same basis. Coburn v. San Mateo County, 75 Fed. 520, 537 et seq. (C.C. Calif., 1896) (similar to Buellton case, county road); Ferris v. Board of Education, 122 Mich. 315, 81 N.W. 98 (1899) (construction of roof so as to cause snow to fall on neighboring land); Schussler v. Board of Comm'rs, 67 Minn. 412, 70 N.W. 6 (1897) (maintenance of dam so as to deprive lower riparian of natural flow). Other cases have criticized these holdings for failing to appreciate the difference between a municipal corporation (which is freely suable though it is not always liable where a private corporation would be) and those quasi-corporations (counties, school districts, etc.) which are created without their voluntary action as mere political subdivisions of the state to perform some of its functions. School Dist. v. Rivera, 30 Ariz. 1, 243 Pac. 609 (1926) ; Zoll v. St. Louis County, 343 Mo. 1031, 124 S.W. 2d 1168 (1938).

The last-mentioned cases certainly support an argument for the state's immunity here. On the other hand there seems to be no basis for distinguishing between the substantive liability (as distinct from any question of suability) of the state and of a municipality exercising governmental functions. Cases holding cities liable may therefore furnish support for the state's liability in a parallel situation, and cases holding counties and school districts liable bolster the availability of municipal cases for this purpose.

${ }^{30}$ Langford v. United States, 101 U.S. 341 (1879); Watkins 78 et seq.; Nichols 451.

In Pennsylvania, compensation for the taking of unimproved land for highways is 
a condition which would be a nuisance if a private person created or maintained it. ${ }^{40}$ Virtually all the state constitutions, however, forbid the taking of private property for public purposes without compensation, ${ }^{41}$ and many of these constitutions forbid both the taking and the damaging ${ }^{42}$ of such property. Most courts have held these provisions to be self-executing, so that even where the legislature fails to provide a procedure for prosecuting such claims against the state, an action may be maintained in the courts to recover compensation whenever there has been a taking or (where that suffices) a damaging of property in the constitutional sense. ${ }^{43}$

The last-mentioned decisions invite the inquiry whether the injury complained of amounts to such a taking, or damaging. The intentional and authorized appropriation of property would, of course, constitute a "taking," but this much is not required. It is enough that defendant's conduct destroys or substantially impairs the use of plaintiff's property either permanently or for a protracted period, as where guns are continually fired over a summer resort ${ }^{44}$ or heavy bombers are continually flown within a hundred feet above a chicken farm. ${ }^{45}$ Consequential damage, however, such as the increased expenses of

regarded as a matter of grace rather than constitutional right, as six per cent was added to all the deeds to the original proprietors, for highway purposes. See, e.g., M'Clenachan v. Curwin, 3 Yeates ( $\mathrm{Pa}$.) 362 (1802) ; Snively v. Washington Township, $218 \mathrm{~Pa}$. 249, 254, 67 Atl. 465, 467 (1907).

${ }^{10}$ United States v. Chicago M. St. P. \& P. R.R., 312 U.S. 592 (1941); United States v. Willow River Power Co., 324 U.S. 499 (1945); Zoll v. St. Louis County, 343 Mo. 1031, 124 S.W. 2d 1168 (1938); In re State Highway Route No. 72, 265 Pa. 369, 108 Atl. 820 (1919).

Cf. United States v. Causby, 328 U.S. 256 (1946), in which the Court was driven either to find a taking or to deny relief, because of the unavailability of recovering on a nuisance theory at least before the Federal Tort Claims Act. Consult notes, 58 Farv. I. Rev. 1252 (1945); 41 Ill. L. Rev. 562 (1946). Consult also Reed v. State, 108 N.Y. 407, 15 N.E. 735 (1888) (where such liability was imposed by virtue of a statute).

The state may also authorize a municipality to do acts in furtherance of a public project which would amount to a nuisance if done by an individual. In such a case the municipality will not be liable unless the legislature so provides. Northern Tr. Co. v. Chicago, 99 U.S. 635 (1878).

${ }^{41}$ Citations are collected in 2 Nichols at $240-41$.

2 Ibid. Consult also ibid., $\$ 6.44$.

${ }^{43}$ Rose v. State, 19 Calif. 2d 713, 123 P. 2d 505 (1942); Chick Springs Water Co. v. State Highway Dep't, 159 S.C. 481, 157 S.E. 842 (1931); note, 2 A.L.R. 2d 677 (1948). Contra: Zoll v. St. Louis County, 343 Mo. 1031, 124 S.W. 2d 1168 (1938).

4 Portsmouth Harbor L. \& H. Co. v. United States, 260 U.S. 327 (1922).

${ }^{45}$ United States v. Causby, 328 U.S. 256 (1946), noted 35 Calif. L. Rev. 110 (1947); 58 Harv. L. Rev. 1252 (1945); 41 Ill. L. Rev. 562 (1946); 95 U. of Pa. I. Rev. 224 (1946). Other examples of nonphysical taking may be found in 2 Nichols $\$ \S 6.3,6.31$; compare ibid., $\$ 6.32$. 
protecting a railroad embankment from high water, ${ }^{46}$ or the loss of "head" for water power, ${ }^{47}$ are not included.

Under constitutional provisions for compensation for damaging property, ${ }^{48}$ recovery may be had for consequential damage which would have been recoverable against an individual if he had caused it $^{49}$ and also for special and peculiar damage by way of "some physical disturbance of a right, either public or private, which the owner of ... land enjoys in connection with his property and which gives it an additional value." ${ }^{.50}$ A typical example is the damage caused to abutting property by the change of grade of a highway. The public project must involve injury to plaintiff's property as an intended or at least necessary consequence of its prosecution, or else the injury must result from a continuous course of conduct amounting to a nuisance. ${ }^{51}$ If the injury is not inevitable but is caused by sporadic acts of negligence ${ }^{52}$ or even trespass ${ }^{53}$ by the state's agents in carrying out the project, the state is not liable. The constitutional provision is held not to cover personal injury or wrongful death. ${ }^{54}$

In determining the state's liability, many American cases reject the distinction between the exercise of proprietary and governmental functions, ${ }^{55}$ which figures so prominently in the case of municipalities. ${ }^{56}$

${ }^{4}$ United States v. Chicago M. St. P. \& P. R.R., 312 U.S. 592 (1941).

${ }^{4}$ United States v. Willow River Power Co., 324 U.S. 499 (1945); 2 Nichols $\$ 6.441$ [2].

Injury to an abutting owner through change of grade of a highway does not constitute a taking in the constitutional sense. In re State Highway Route No. $72,265 \mathrm{~Pa} .369,108$ Atl. 820 (1919) ; see Chicago v. Taylor, 125 U.S. 161 (1888); Hickman v. City of Kansas, 120 Mo. 110, 25 S.W. 225 (1894); Swift \& Co. v. Newport News, 105 Va. 108, 52 S.E. 821 (1906).

${ }^{4} 2$ Nichols $\$ 6.44$.

${ }^{4 s}$ Ibid., $\$ 6.441$ [2].

${ }^{50}$ Ibid., $\$ 6.441$ [3]. Damages resulting from change of grade were allowed in the Taylor, Hickman, and Swift \& Co. cases, note 47 supra.

${ }^{51}$ See note, 2 A.L.R. 2d 677, 681, 690-92 (1948).

${ }^{52}$ Hughes v. United States, 230 U.S. 24 (1913) ; Sanguinetti v. United States, 264 U.S. 146 (1924); Angelle v. State, 212 La. 1069, 34 So. 2 d 321 (1948); note, 2 A.L.R. 2d 677 (1948).

${ }^{\varpi}$ People v. Bueliton Dev. Co., 58 Calif. App. 2d 178, 136 P. 2d 793 (1943). Compare cases cited note 38 supra.

${ }^{54}$ Brandenburg v. Los Angeles County Flood Control Dist., 45 Calif. App. 2d 306, 114 P. 2d 14 (1941); Braunstein v. Louisville, $146 \mathrm{Ky} .777,143$ S.W. 372 (1912); note, 2 A.L.R. 2d 677, 707-11 (1948).

$\approx$ Ballaine v. Alaska Northern Ry., 259 Fed. 183 (C.A. 9th, 1919) (railroad); State v. Hill, $54 \mathrm{Ala}_{4} 67$ (1875) (same); Rauschan v. State Comp. Ins. Fund, 80 Calif. App. 754, 253 Pac. 173 (1927) ; Riddoch v. State, 68 Wash. 329, 123 Pac. 450 (1912) ; Borchard, op. cit. supra note 2, 34 Yale L. J. 1, 16 (1924); note, 8 A.L.R. 995 (1920).

${ }^{56}$ See pp. 622 et seq. infra. 
The latter "are only sovereign and only immune in so far as they represent the state; . . . their immunity, like their sovereignty, is in a sense borrowed ... [but] the state is inherently sovereign at all times and in every capacity. ${ }^{357}$ While this reasoning is a logical enough deduction from the premises assumed, yet, as previously indicated, the whole matter of sovereign immunity is so questionable from the points of view of history, comparative law, and policy, that any application of the notion which extends rather than cuts down immunity may be and has been questioned..$^{58}$ And the expansion of government-accelerated during the present century-into activities which were formerly left largely to private enterprise which had to pay for its torts should not prevent the victims of those activities from obtaining the compensation they otherwise would have had. As the California court has recently said, considerations of embarrassment and expense to the state "are no longer persuasive in relation to an industrial or business enterprise which by itself may be looked to for the discharge of all appropriate demands and expenses growing out of operations."

If the state sets up a corporation to carry out some of its functions, it may endow the corporation with its own immunity, ${ }^{60}$ although of course it need not; ${ }^{61}$ if it does not do so affirmatively, the corporation will be liable just as any agent of the state would be. ${ }^{62}$ If the state acquires stock in an existing corporation, the latter does not become endowed with immunity. ${ }^{83}$

${ }^{57}$ Riddoch v. State, 68 Wash. 329, 334-35, 123 Pac. 450, 452 (1912).

${ }^{5}$ People v. Superior Court, 29 Calif. 2d 754, 178 P. 2d 1 (1947) (making the distinction and holding the state for negligent operation of its railroad); Guidi v. State, 41 Calif. 2d 623, 262 P. 2d 3 (1953) (same for state fair); Maguire, State Liability for Tort, 30 Harv. L. Rev. 20 (1916) (urging the distinction). Cf. Western \& A. R.R. v. Carlton, 28 Ga. 180 (1859); authorities cited note 70 infra (dealing with similar problem as to counties). Consult also Bakken v. State, 56 N.D. 861,219 N.W. 834 (1928) (dealing with statute).

${ }^{60}$ People v. Superior Court, 29 Calif. 2d 754, 762, 178 P. 2d 1, 6 (1947).

${ }^{\infty}$ Keifer \& Keifer v. R.F.C., 306 U.S. 381, 388-91 (1939). Cf. Ballaine v. Alaska Northern Ry., 259 Fed. 183 (C.A. 9th, 1919).

${ }^{\text {or }}$ See Keifer \& Keifer v. R.F.C., 306 U.S. 381, 390-91 (1939), listing some forty corporations created by the federal government in the two decades before the decision, all of which had been made suable by Congress.

${ }^{2}$ Sloan Shipyards v. U.S. Shipping Board E.F. Corp., 258 U.S. 549 (1922); cf. Keifer \& Keifer v. R.F.C., 306 U.S. 381 (1939). But cf. Ballaine v. Alaska Northern Ry., 259 Fed. 183 (C.A. 9th, 1919) (immunity accorded to corporation where all assets and securities had been acquired by federal government). The question is primarily one of statutory construction, but the point of view from which this question is approached will be crucial where the statute is not explicit.

${ }^{\infty}$ Bank of U.S. v. Planters Bank of Georgia, 9 Wheat. (U.S.) 904 (1824). But cf. Ballaine v. Alaska Northern Ry., 259 Fed. 183 (C.A. 9th, 1919), note 62 supra (all stocks, bonds, and assets acquired). 
A contractor performing work for a governmental body shares its immunity "[i]f the injury result not from negligence but from the fact that the work is performed at all, ${ }^{64}$ or from the failure to perform it, ... but not so, if the injury results from the negligent manner in which the work is done."165

2. Counties, Townships, Taxing Districts, etc. These political subdivisions of a state have probably always been considered immune in this country. ${ }^{68}$ The first few cases contained little discussion; but early Massachusetts cases elaborated a distinction between corporations created for their own profit and quasi-corporations, like counties, which were merely "the inhabitants of any district, who are by statute invested with particular powers without their consent" and "created by the legislature for purposes of public policy." ${ }^{\text {67 }}$ The leading American case also involved a "sorry misapplication" case of Russell v. Men of Devon ${ }^{69}$ A qualified immunity for counties and other quasi-corporations represents the prevailing view today, though "the current trend of decisions supports the view that a county does in some cases exercise private or proprietary functions for which [it] may be liable in tort. ${ }^{270} \mathrm{New}$ York has held that the immunity of

" Cf. Chargois v. Grimmett \& James, 36 So. 2d 390 (La. App., 1948) (contractor not liable for trespass in pursuance of directions of and contract with department of public works); Ference v. Booth \& Flinn Co., 370 Pa. 400, 88 A. 2d 413 (1952) (where obstruction of one highway necessarily caused by work done pursuant to contract with state in constructing another, contractor's only duty is one of care to prevent obstruction from being unreasonably prolonged. Dissent on ground that on facts of this case delay was unreasonably long).

${ }^{\infty}$ Trigg v. H. K. Ferguson Co., 30 Tenn. App. 672, 680, 209 S.W. 2d 525, 529 (1947) (holding federal government's contractor for defective condition of highway caused by it).

Cases in which the contractor has been held for his negligence in the course of performing work for a governmental body include State Const. Co. v. Johnson, $82 \mathrm{Ga}$. App. 698, 62 S.E. 2d 413 (1950); Taylor v. Westerfield, 233 Ky. 619, 26 S.W. 2d 557 (1930) (overruling former cases which had exempted contractor on grounds that this would lessen expense of such contracts to the government. An excellent opinion); Stiers v. Mayhall, 207 Okla. 219, 248 P. 2d 1047 (1952).

${ }^{\infty}$ Sheldon v. County of Litchfield, 1 Root (Conn.) 158 (1790); Hurlburt v. Marsh, 1 Root (Conn.) 520 (1793).

${ }^{67}$ Mower v. Leicester, 9 Mass. 247, 250 (1812); cf. Riddle v. Proprietors of the Locks \& Canals on Merrimack River, 7 Mass. 169, 187 (1810).

${ }^{*}$ Barnett, Foundations of the Distinction between Public \& Private Functions in Respect to the Common Law Tort Liability of Municipal Corporations, 16 Ore. L. Rev. 250, 264 (1937). Compare Borchard, op. cit. supra note 2, 34 Yale L. J. 1, 41 et seq. (1924).

${ }^{\infty} 2$ Durn. \& E. 667 (K.B., 1788). Some of the reasons given for this decision (e.g., that the county was not an entity, and that it had no funds nor means of acquiring any) had no application to New England towns. See authorities cited note 68 supra.

${ }^{70}$ Note, 16 A.L.R. 2d 1079, 1080 (1951). Consult, e.g., Granite Oil Securities, Inc. v. Douglas County, 67 Nev. 388, 219 P. 2d 191 (1950); Rhodes v. Asheville, 230 N.C. 134, 
her political subdivisions fell with the removal of the state's own immunity, which they had merely shared. ${ }^{71}$

3. Municipal Corporations. The American rules governing the tort liability of municipal corporations make a curious patchwork of immunity and responsibility. The dominant motif is a supposed distinction between governmental and proprietary functions. In performing the latter the municipality generally is liable in much the same way as a private individual or private corporation would be, ${ }^{72}$ though the problem sometimes is complicated by distinctions between misfeasance and nonfeasance, ${ }^{73}$ and between ministerial and discretionary acts, ${ }^{74}$ in a way that is peculiar to public bodies. In performing governmental functions the municipality is generally accorded an immunity not unlike that of the state, ${ }^{75}$ though there are exceptions ${ }^{76}$ and sub-distinctions ${ }^{77}$ that make the pattern more irregular.

The dominant governmental-proprietary distinction did not appear in most of the earlier American cases. ${ }^{78}$ It has been suggested that it was a product of benevolent judicial legislation to temper the harsh-

52 S.E. 2d 371 (1949); cases collected in notes, 16 A.L.R. 2d 1079 (1951); 101 A.L.R. 1166 (1936).

The older, stricter notion of a county's immunity is in general disfavor with commentators. Consult, e.g., Barnett, op. cit. supra note 68; Borchard, op. cit. supra note 68; Tort Claims against the State of nlinois and its Subdivisions, 47 Nw. U. L. Rev. 914, 921 (1953).

${ }^{71}$ Holmes v. County of Erie, 266 App. Div. 220, 42 N.Y.S. 2d 243 (4th Dep't, 1943), aff'd 291 N.Y. 798, 53 N.E. 2d 369 (1944) ; Bernardine v. City of New York, 294 N.Y. 361, 62 N.E. 2d 604 (1945) ; Lloyd, Municipal Tort Liability in New York, 23 N.Y.U.L. Rev. 278 (1948). Consult Tort Claims against the State of Illinois and Its Subdivisions, $47 \mathrm{Nw}$. U. L. Rev. 914, 920-21 (1953).

72 For some treatments of municipal liability, in all of which the distinction between governmental and proprietary functions is pointed out, see Borchard, op. cit. supra note 2, 34 Yale L. J. 129 (1924); Doddridge, Distinction between Governmental and Proprietary Functions of Municipal Corporations, 23 Mich. L. Rev. 325 (1925) ; Tooke, Extension of Municipal Liability in Tort, 19 Va. L. Rev. 97 (1932); Seasongood, Municipal Corporations: Objections to the Governmental or Proprietary Test, 22 Va. L. Rev. 910 (1936); Barnett, op. cit. supra note 68 ; Hobbs, Tort Liability of Municipalities, 27 Va. L. Rev. 126 (1940) ; Fuller \& Casner, Municipal Tort Liability in Operation, 54 Harv. L. Rev. 437 (1941) ; Repko, American Legal Commentary on the Doctrines of Municipal Tort Liability, 9 Law \& Contemp. Prob. 214 (1942) ; Lloyd, op. cit. supra note 71; Smith, Municipal Tort Liability, 48 Mich. L. Rev. 41 (1949); note, 120 A.L.R. 1376 (1939).

${ }^{73}$ See p. 627 infra.

${ }^{7}$ See pp. 627-28 infra.

${ }^{25}$ See authorities cited note 72 supra.

${ }^{70}$ See p. 629 infra.

${ }^{\pi}$ See n. 108 infra.

${ }^{38}$ The earliest case seems to be Hooe v. Alexandria, 12 Fed. Cas. 461 , No. 6666 (C.C. D.C., 1802). Other early cases are collected in Barnett, op. cit. supra note 68 at 259 n. 35. 
ness of governmental immunity. ${ }^{79}$ The earlier cases, however, seem to have imposed-rather than withheld-liability without regard to the distinction, ${ }^{80}$ which first made its way into prominence in the mid-nineteenth-century case of Bailey $v$. City of New York..$^{81}$ It may have reflected in part the distinction between public and private corporations which had been developed for the entirely different purpose of determining which entities were entitled to "the protection of the obligation of contracts" against legislative modification. ${ }^{82}$ However that may be, the present distinction is commonly rationalized by saying that the municipality is the agent or representative of the state in performing governmental functions and so shares the state's immunity, but that it has no sovereignty and no immunity of its own. ${ }^{83}$ So far as policy reasons go, those offered for the state's immunity are generally repeated but with special emphasis on the fear of municipal bankruptcy. ${ }^{84}$

No satisfactory test has been devised for distinguishing governmental from proprietary functions. ${ }^{85}$ The state legislature has wide powers to determine the nature of a duty which it imposes or a privilege which it confers upon a municipal corporation. ${ }^{86}$ But the legislature rarely speci-

To 1 Dillon, Law of Municipal Corporations $\$ 111$ (5th ed., 1911) (hereafter cited as Dillon).

${ }^{\infty}$ Authorities cited note 78 supra; Lloyd, op. cit. supra note 71.

${ }^{\text {s1 }} 3$ Hill (N.Y.) 531 (1842).

82 Barnett, op. cit. supra note 68 , at 253-55.

${ }^{83}$ Consult, e.g., Krantz v. City of Hutchinson, 165 Kan. 449, 196 P. 2d 227 (1948); Hoggard v. Richmond, 172 Va. 145, 200 S.E. 610 (1939); Doddridge, op. cit. supra note 72, at 333. Cf. Bernardine v. City of New York, 294 N.Y. 361, 62 N.E. 2d 604 (1945).

s\& Warp, Tort Liability Problems of Small Municipalities, 9 Law \& Contemp. Prob. 363 (1942); Fuller \& Casner, op. cit. supra note 72.

Studies aimed at ascertaining the actual burden are described in the two articles just cited, and also in David \& French, Public Tort Liability Administration: Organization, Methods, and Expense, 9 Law \& Contemp. Prob. 348 (1942); Warp, Law and Administration of Municipal Tort Liability, $28 \mathrm{Va}$. L. Rev. 360 (1942) (concluding, at 376: "In no instance ... is the present cost excessively great, and in no instance does it appear that the abolition of immunity would raise the cost to a prohibitive figure").

See authorities cited notes 72 supra and 94 infra.

${ }^{86}$ Abbott v. Des Moines, 230 Iowa 494, 298 N.W. 649 (1941) (airport) ; MacMullen v. Middletown, 187 N.Y. 37, 46, 79 N.E. 863,866 (1907) (maintenance of highways: "If, in investing the municipality with the duty, the legislature should regard its performance as partaking of a governmental nature and should relieve it of responsibility for breaches, could it properly be said to have violated any constitutional rights of the citizens? I think not") ; Stocker v. Nashville, 174 Tenn. 483, 126 S.W. 2 d 339 (1939) (airport); Van Gilder v. Morgantown, 136 W. Va. 831, 68 S.E. 2d 746 (1949; dissent 1952) (airport); note, 124 A.L.R. 350 (1940). But cf. Christopher v. EI Paso, 98 S.W. 2 d 394 (Tex. Civ. App., 1936).

The statute in the Abbott and Stocker cases expressly excluded liability; that in Van 
fies whether a function is to be governmental or proprietary, and, where it gives no clear guide, the courts resort to one or more of several criteria in making the determination. Those most often invoked are (1) whether the function is allocated to the municipality for its profit or special advantage or whether for the purpose of carrying out the public functions of the state without special advantage to the city ${ }^{87}$ and (2) whether the function is one historically performed by government. "[I]t is only where the duty is a new one, and is such as is ordinarily performed by trading corporations, that an intention to give a private action for a neglect in its performance is to be presumed.

These criteria are elusive and unsatisfactory. All the functions of a municipality are-or should be-for the public benefit. They are none the less so because they serve directly and primarily only a limited segment of the public rather than all the people of the state. To the extent that cities are instrumentalities of the state, their main function is to serve the state's purposes locally. ${ }^{89}$ The fact that the municipality makes a charge or a profit in connection with the service rendered has often been considered; ${ }^{90}$ but functions have been held governmental

Gilder did not, but declared that the acquisition, operation, etc., of airports were to be "public and governmental functions." Other cases have interpreted similar language as making an airport a public purpose only to authorize public expenditures, etc. Rhodes v. Asheville, 230 N.C. 134, 52 S.E. 2d 371, reh. denied 230 N.C. 759, 53 S.E. 2d 313 (1949); notes, 15 Ga. B. J. 79 (1952); 27 Notre Dame Lawyer 645 (1952); 38 Va. L. Rev. 699 (1952); 54 W. Va. L. Rev. 322 (1952).

${ }^{87}$ In a much-quoted passage, the Massachusetts court has said, "The underlying test is whether the act is for the common good of all without the element of special corporate benefit or pecuniary profit." Bolster v. Lawrence, 225 Mass. 387, 390, 114 N.E. 722, 724 (1917). Ashbury v. Norfolk, 152 Va. 278, 288, 147 S.E. 223, 226 (1929) ; 18 McQuillin, Law of Municipal Corporations $\$ 53.29$ (3d ed., 1949) (hereafter cited as McQuillin).

Cf. Cowin \& Co. v. Merrill, 202 Wis. 614, 233 N.W. 561 (1930).

${ }^{8}$ Hill v. Boston, 122 Mass. 344, 369 (1877) (the statement was confined to functions which served the public benefit and not the pecuniary advantage of the municipality), quoted in 4 Dillon $\$ 1643$.

${ }^{80}$ Take the cases of fire protection and education for examples of functions which are universally regarded as governmental. The direct benefits enure fairly exclusively to the local citizens. Wider public benefits there undoubtedly are in a most important sense but they come as a consequence of conferring the benefit upon local people and local property. See also analysis in Borchard, op. cit. supra note 2, 34 Yale L. J. 129, 136 (1924).

${ }^{20}$ Beard v. San Francisco, 79 Calif. App. 2d 753, 180 P. 2d 744 (1947); Bolster v. Lawrence, 225 Mass. 387, 114 N.E. 722 (1917) (city not liable for "gratuitous performance of strictly public functions . . . from which is derived no special corporate advantage, no pecuniary profit, and no enforced contribution from individuals particularly benefited").

Cf. Griffin v. Salt Lake City, 111 Utah 94, 176 P. 2d 156 (1947), where the fact that a fee was charged for entrance to a city swimming pool was considered but not treated as 
in spite of a charge, ${ }^{01}$ and functions have been held proprietary where there is neither charge nor profit. ${ }^{22}$ The historical test is a suggestive guide though a faltering one. Many of the functions now generally considered governmental were privately performed in the not very distant past. $^{.3}$ Little wonder that courts ${ }^{94}$ and commentators ${ }^{95}$ have despaired of finding a rational and consistent key to the distinction. Yet it has remained as part of our American law, and lawyers and courts are faced with the practical problem of applying it. The only safe guides are precedent and the underlying attitude toward contraction or expansion of municipal liability with which the problem is approached. ${ }^{96}$

conclusive. Nor was the fact that the city incurred a deficit on the whole operation, which was held proprietary on all the facts in the case. Compare authorities cited note 108 infra.

${ }^{21}$ Kellar v. Los Angeles, 179 Calif. 605, 178 Pac. 505 (1919) (charge made for children's summer camp); Watkins v. Toccoa, 55 Ga. App. 8, 189 S.E. 270 (1936) (city derived profit from manufacture and installation of sanitary toilets); Rhoades v. School Dist. No. 1, 115 Mont. 352, 142 P. 2d 890 (1943) (admission fee for school basketball game).

${ }^{82}$ See, e.g., Roumbos v. Chicago, 332 III. 70, 77, 163 N.E. 361, 364 (1928) (Street-cleaning held proprietary. The test "does not refer to a pecuniary advantage to the municipality or its inhabitants but to the nature of the act or transaction in question, whether affecting primarily the interest of the locality or inhabitants of the city or the general public"); Missano v. New York, 160 N.Y. 123, 54 N.E. 744 (1899) (same). There is a split of authority on the classification of this function. Note, 156 A.L.R. 692 (1945); Hoggard v. Richmond, 172 Va. 145, 200 S.E. 610 (1939) (free municipal swimming pool, noting conflict among authorities); $18 \mathrm{McQuillin} \S 53.125$ (repair of sewers a proprietary function).

${ }^{23}$ See Seasongood, op. cit. supra note 72, at 914-15: "There was a time when sewage facilities were furnished by private companies, as was garbage and rubbish collection. Yet the planning of sewers (... as opposed to the operation and upkeep of sewers) and the collection and disposal of garbage and ashes are all but universally regarded as governmental. The London police force was not established until 1829. It is not a hundred years since fire companies were generally private and voluntary."

24 Consult, e.g., Hoggard v. Richmond, 172 Va. 145, 200 S.E. 610 (1939). At one time the Ohio court noted the confusion and cut the Gordian Knot by repudiating the distinction and imposing tort liability [Fowler v. Cleveland, 100 Ohio 158, 126 N.E. 72 (1919) ], but this bold step was retraced four years later. Aldrich v. Youngstown, 106 Ohio 342, 140 N.E. 164 (1922). The South Carolina court solved the problem in exactly the opposite way, by repudiating the distinction and affording the immunity broadly. Irvine v. Greenwood, 89 S.C. 511, 72 S.E. 228 (1911). The Florida court has repudiated the distinction where there is a city-manager form of government. Kaufman v. Tallahassee, 84 Fla. 634, 94 So. 697 (1922).

${ }^{\infty 5}$ See authorities cited note 72 supra.

${ }^{\circ}$ Contrast, for example, Krings v. Bremerton, 22 Wash. 2d 220, 155 P. 2d 493 (1945) (holding garbage collection governmental), with Hutton v. Martin, 41 Wash. 2d 780, 252 P. 2d 581 (1953), noted in 28 Notre Dame Lawyer 427 (1953) (overruling Krings, reasoning that since the legislature had provided no immunity when it authorized municipal utilities, "the court should find no implied immunity from tort liability"). Contrast also Savannah v. Lyons, 54 Ga. App. 661, 189 S.E. 63 (1936) (airport governmen- 
So far as precedent goes, the following activities illustrate those which are generally held to be governmental: legislative activity (such as the passage or repeal of, or failure to pass, an ordinance) $;^{97}$ the failure to enforce laws or abate nuisances; ${ }^{98}$ police activity; ${ }^{99}$ fire-fighting; ${ }^{100}$ education; ${ }^{101}$ and public health. ${ }^{102}$ On the other hand the opera-

tal), with Caroway v. Atlanta, 85 Ga. App. 792, 70 S.E. 2 d 126 (1952) (airport proprietary), noted in $15 \mathrm{Ga}$. B. J. 79 (1952), which suggests such an explanation for the difference in holdings.

See also Warp, Law and Administration of Municipal Tort Liability, 28 Va. L. Rev. 360 (1942) ; note, 38 Va. L. Rev. 699 (1952) ; and cf. Granite Oil Securities, Inc. v. Douglas County, 67 Nev. 388, 219 P. 2d 191 (1950).

${ }^{9 \tau}$ See, e.g., Shipley v. Arroyo Grande, 92 Calif. App. 2d 748, 208 P. 2d 51, 53 (1949) (failure to repeal "ancient ordinance" permitting diagonal parking could afford no basis of liability); Tolliver v. Newark, 145 Ohio 517, 62 N.E. 2d 357 (1945) (designating one street rather than another as stop street); Jones v. Williamsburg, 97 Va. 722, 34 S.E. 883 (1900) (failure to pass ordinance forbidding bicycles on sidewalk); note, 116 A.L.R. 1404 (1938); 4 Dillon $\$ 1627$; 18 McQuillin $\$ 56.36$. But cf. Baillie v. Wallace, 24 Idaho 706, 135 Pac. 850 (1913) (duty of care to maintain streets cannot be evaded by failure to pass ordinance concerning signs over sidewalk).

The failure to provide for traffic signals or to keep them in repair is generally considered a breach of governmental function. Tolliver v. Newark, supra; Loehe v. Fox Point, 253 Wis. 375, 34 N.W. 2d 126 (1948), noted in 33 Marq. L. Rev. 74 (1949). But cf. Johnston v. East Moline, 405 Ill. 460, 91 N.E. 2d 401 (1950), noted in [1950] IIl. L. For. 298. This is the kind of negligence for which there would be liability under a broad waiver of governmental immunity. Foley v. New York, 294 N.Y. 275, 62 N.E. 2d 69 (1945).

${ }^{88}$ Udkin v. New Haven, 80 Conn. 291, 68 Atl. 253 (1907) (failure to abate condition on private land causing ice on sidewalk); Wilmington v. Vandegrift, 1 Marv. (Del.) 5 , 29 Atl. 1047 (1893) (failure to prevent coasting in street) ; Roberson v. District of Columbia, 86 A. 2d 536 (Mun. App. D.C., 1952) (failure to prevent loitering); Lafayette v. Timberlake, 88 Ind. 330 (1882) (failure to prevent coasting); Harris v. Des Moines, 202 Iowa 53, 209 N.W. 454 (1926) (failure to exclude traffic from street set aside for coasting); Loth v. Columbia Theatre Co., 197 Mo. 328, 94 S.W. 847 (1906) (failure to enforce ordinance concerning signs over walk); Chaney v. Riverton, $104 \mathrm{Neb} .189,177$ N.W. 845 (1920) (failure to disperse crowd in street); Doughty v. Philadelphia R. T. Co., $321 \mathrm{~Pa}$. 136, 184 Atl. 93 (1936) (letting trolley run wrong way on one-way street); Weller v. Burlington, 60 Vt. 28, 12 Atl. 215 (1887) (coasting); Schultz v. Milwaukee, 49 Wis. 254, 5 N.W. 342 (1880) (coasting). But cf. Taylor v. Mayor of Cumberland, 64 Md. 68, 20 Atl. 1027 (1885).

${ }^{90}$ Miami v. Bethel, 65 So. 2d 34 (Fla., 1953) (assault and battery by police officer), noted in 6 Ala. L. Rev. 119 (1953); 4 Dillon \$1656;18 McQuillin $\$ 53.51$. Note that most of the cases cited in note 98 supra involve an alleged failure by the police authorities.

${ }^{100}$ Florio v. Jersey City, 101 N.J.L. 535, 129 At1. 470 (1925); 4 Dillon $\$ 1660 ; 18$ McQuillin $\$ 53.52$.

${ }^{100}$ Lambert v. New Haven, 129 Conn. 647, 30 A. 2d 923 (1943); 4 Dillon \$ 1658. Cf. Bang v. Independent School Dist. No. 27, 177 Minn. 454, 225 N.W. 449 (1929); Benton v. Board of Ed., 201 N.C. 653, 161 S.E. 96 (1931); Boice v. Board of Ed., 111 W. Va. 95, 160 S.E. 566 (1931); note, 160 A.T.R. 7 (1946). In the usual case where the function of education is administered by a school district or other quasi-corporation, there is a basis for immunity which may not generally depend on the,governmental-proprietary distinction. See authorities cited notes 38 and 58 supra.

${ }^{102} 4$ Dillon $\$ 1661$. 
tion and maintenance of utilities (waterworks, sewer systems, gas or electric plants, street railways, airports) are generally regarded as proprietary functions. ${ }^{103}$ There is conflict among the authorities as to street-cleaning, ${ }^{104}$ garbage collection, ${ }^{105}$ parks, ${ }^{106}$ swimming pools, ${ }^{107}$ and the erection and maintenance of public buildings. ${ }^{108}$ Streets and highways deserve separate treatment.

Even where a function is proprietary the municipality may have a choice of whether it will undertake the function at all and how such undertaking will be made. Some of the choices are clearly discretionary ones of a political or legislative kind. No liability, for instance, should attach to the failure to make an affirmative choice to acquire or construct a utility, or to extend its services. This, it is submitted, is the only proper application (in this connection) of the notion that a municipality is not liable for nonfeasance. ${ }^{109}$ The municipality is also properly exempted from liability for the consequences of broadly choosing to perform a proprietary function one way rather than another, e.g., to carry utility wires overhead rather than in underground conduits, or to buy power from existing plants rather than to erect new ones. Once

\footnotetext{
${ }^{103} 18 \mathrm{McQuillin} \$ 53.100$ et seq. Nice questions may arise if the services of the utility are used only, or in part, for governmental purposes. See Aschoff v. Evansville, 34 Ind. App. 25, 72 N.E. 279 (1904); note, 43 L.R.A. (N.S.) 862, 866 (1913).

${ }^{104} 4$ Dillon $\$ 1662$; 18 McQuillin $\$ 53.46$; note, 156 A.L.R. 692 (1945).

${ }^{100}$ See Hutton v. Martin, 41 Wash. 2d 780, 252 P. 2d 581 (1953); 4 Dillon $§ 1662 ; 18$ McQuillin §53.46.

${ }^{100}$ See cases collected in notes of which latest is 142 A.L.R. 1340 (1943). Cf. Heitman v. Lake City, 225 Minn. 117, 30 N.W. 2d 18 (1947).

${ }^{100}$ For recent cases which collect the authorities, see Felton v. Great Falls, 118 Mont. 586, 169 P. 2d 229 (1946); Hoggard v. Richmond, 172 Va. 145, 200 S.E. 610 (1939).
}

${ }^{108}$ If the building is maintained and used exclusively for the accommodation of a governmental function, the rule of immunity is generally applied. Lambert v. New Haven, 129 Conn. 647, 30 A. 2d 923 (1943) (school building); Beakey v. Billerica, 324 Mass. 290, 85 N.E. 2d 620 (1949) (town infirmary); Kraeling v. Dormont, 352 Pa. 644, 44 A. 2d 274 (1945) (poiling place); 4 Dillon $\$ \$ 1657-58 ; 18 \mathrm{McQuillin} \$ \$ 53.92$ et seq.

If, on the other hand, the building is devoted exclusively to proprietary functions, there should be no immunity. Rhodes v. Palo Alto, 100 Calif. App. 2d 336, 223 P. 2d 639 (1950) (community theater and auditorium); Muses v. Housing Authority, 83 Calif. App. 2d 489, 189 P. 2d 305 (1948) (housing rental units).

Conflict appears where part of the building is rented commercially or where part of it houses proprietary functions, but where it is also used for governmental purposes. See, e.g., Banks v. Downing, 78 A. 2d 865 (Del. Super., 1951); Oliver v. Worcester, 102 Mass. 489 (1869); Beakey v. Billerica, supra; Pleasants v. Greensboro, 192 N.C. 820, 135 S.E. 321 (1926); Bell v. Pittsburgh, 297 Pa. 185, 146 Atl. 567 (1929); Hartness v. Allegheny County, 349 Pa. 248, 37 A. 2 d 18 (1944); Lowe v. Salt Lake City, 13 Utah 91, 44 Pac. 1050 (1896); Buchanan v. Barre, 66 Vt. 129, 28 Atl. 878 (1894); note, 64 A.L.R. 1545 (1929).

${ }^{100}$ Compare text at p. 647 infra and analysis in 4 Dillon $\$ 1626$. 
these broad policy decisions have been made, however, the municipality should be held accountable to the same extent as a private enterprise would be for the adoption of a plan or design (in carrying out the project) which is unreasonably dangerous by the ordinary tests of negligence. ${ }^{110}$ A good many decisions are consistent with the view here set forth. But some courts, unwarrantably it is believed, have refused to hold a municipality liable for the adoption of an unsafe subordinate plan or design on the ground that this involves the exercise of discretion, ${ }^{111}$ or have been willing to do so only where the condition produced "is so manifestly dangerous that a court upon the facts can say, as a matter of law, that it was dangerous and unsafe."112

\footnotetext{
${ }^{200}$ Perrotti v. Bennett, 94 Conn. 533, 109 Atl. 890 (1920) (recognizing, however, rule of "non-liability for error in the adoption of the plan" but declaring that "[c]ases to which the doctrine is applicable are not numerous." Liability imposed for improperly protected drain. Opinion seems to leave immunity only where plan involved non-negligent error in judgment); North Vernon v. Voegler, 103 Ind. 314, 2 N.E. 821 (1885) (city not liable for mere error in judgment in adopting plan, but is if this amounts to negligence); Klipp v. Hoyt, 99 Kan. 14, 160 Pac. 1000 (1916) (explaining Gould v. Topeka, 32 Kan. 485, $4 \mathrm{Pac} .822$ (1884), and stating a rule of ordinary care); Lebanon v. Graves, $178 \mathrm{Ky} .749$, 199 S.W. 1064 (1918) ("it makes little, if any, substantial difference . . . whether the ... dangerous condition ... was due to a defective plan, or due to conditions that the city permitted to come up after the construction of the street"); cf. District of Columbia v. Harper, 40 App. D.C. 568 (1913) (failure to remove seepage caused by plan of construc-
} tion which had originally been questioned).

Consult also note, 90 A.L.R. 1502, 1503 (1934) (in stating general rule of non-liability for plan, the courts "by numerous limitations, qualifications, and provisos have left little scope for its actual operation") ; 18 McQuillin $\$ 53.122$ (favoring "Indiana rule," though stating it as minority rule).

${ }^{111}$ An unfortunate example is Coffey v. Berkeley, 170 Calif. 258, 149 Pac. 559 (1915). See also cases cited in note, 90 A.L.R. 1502 (1934); $18 \mathrm{McQuillin} \S 53.121$ (sewers); 19 ibid., at $\$ 54.61$; note, 173 A.L.R. 1031 (1948) (sewers).

Even under this "general rule," "exceptions" are numerous. There will be liability, for instance, for negligent execution of the plan, or for negligent maintenance of the highway or sewer so that defects develop, or for failure to secure competent advice in adopting the plan as the sources cited above show. And some cases hold the city for conditions attributable to the original plan after an experimental period. Norfolk v. Hall, 175 Va. 545, 9 S.E. 2d 356 (1940).

${ }^{112}$ Gould v. Topeka, 32 Kan. 485, 493, 4 Pac. 822, 827 (1884) (but cf. Klipp v. Hoyt, 99 Kan. 14, 160 Pac. 1000 (1916). To the same effect are Healy v. Chicago, 131 IIl. App. 183 (1907); Quest v. Upton, 36 Wyo. 1, 252 Pac. 506 (1927).

It is often said that the city may be held if the plan is "palpably" defective or involved gross error. Conlon v. St. Paul, 70 Minn. 216, 72 N.W. 1073 (1897); Henson v. Kansas City, 277 Mo. 443, 210 S.W. 13 (1919); cf. Reed v. Tarentum, 213 Pa. 357, 62 Atl. 928 (1906) (reasonable safety of plans "to be determined by the standard of ordinary usage").

These rules which apply a standard of conduct variant from that of ordinary care are reminiscent of earlier, now generally discarded, rules exonerating an industry of negligence if it adopted customary devices and methods, or plans which had the approval of respectable expert opinion, etc. See Baltimore \& O. R.R. v. Groeger, 266 U.S. 521 (1925); James and Sigerson, Particularizing Standards of Conduct in Negligence Trials, 5 Vand. L. Rev. 697 (1952). Such vestigial notions linger today only where the law is especially tender toward a class of defendants, such as doctors, or cities. 
Even with respect to functions which fall within the proprietary class, the municipality is not liable for acts which are wholly ultra vires, ${ }^{113}$ but this notion does not shield it from liability for negligent or other tortious acts done in the course of activities within the municipality's general power. ${ }^{114}$

Where injury is caused in the performance of a governmental function the municipality may nevertheless be liable for the torts of its officers where these involve either a taking ${ }^{115}$ or a direct trespass to real estate, ${ }^{116}$ or the creation or maintenance of a nuisance. ${ }^{117}$ The concept of nuisance here includes a condition which entails unreasonable danger to persons exercising a public right, such as the use of highways, or public schools or parks. ${ }^{118}$

Streets and Sidewalks. Municipalities in this country are generally subject to liability today for injuries caused by defects in highways within their borders. ${ }^{119}$ The bases of liability, however, differ among the jurisdictions. In New England and a few other states there was no common-law liability on the part of any political subdivision (including the town) for such injuries. ${ }^{120}$ In these states today such liability rests entirely upon statute ${ }^{121}$ unless the condition amounts to a nuisance created or maintained by the town. ${ }^{122}$ In other states liability has been

15s 4 Dillon $\$ 1650-54 ; 18 \mathrm{McQuillin} \$ \$ 53.60-64$.

${ }^{114}$ Krantz v. Hutchinson, 165 Kan. 449, 196 P. 2d 227 (1948); Thayer v. Boston, 36 Mass. 511 (1837); compare text at p. 000 infra; authorities cited note 113 supra.

${ }^{115}$ See text at p. 618 supra.

${ }^{110}$ Weed v. Greenwich, 45 Conn. 170 (1877) ; Lee v. Sandy Hill, 40 N.Y. 442 (1869); Persons v. Valley City, 26 N.D. 342,144 N.W. 675 (1913); 18 McQuillin \$53.11. Cf. Barrows v. Sycamore, 150 IIl. 588, 37 N.E. 1096 (1894) (obstruction of light, etc.); Thayer v. Boston, 36 Mass. 511 (1837).

${ }^{217}$ Langley v. Augusta, 118 Ga. 590, 45 S.E. 486 (1903); Holl v. Merrill, 251 Wis. 203, 28 N.W. 2d 363 (1947); 18 McQuillin $\$ \$ 53.12,53.47-.50$. Compare authorities cited note 116 supra and the present note with authorities cited notes 38-40 supra.

${ }^{118}$ Bush v. Norwalk, 122 Conn. 426, 189 Atl. 608 (1937) (school) ; note, 160 A.L.R. 7, 70-74 (1946) (showing split of authority, some cases limiting recovery against school district to nuisances damaging property); McCarton v. New York, 149 App. Div. 516, 133 N.Y. Supp. 939 (1st Dep't, 1912) (school) ; Bacon v. Rocky Hill, 126 Conn. 402, 11 A. 2d 399 (1940) (highway); Murphy v. Farmingdale, 252 App. Div. 327, 299 N.Y. Supp. 586 (2d Dep't, 1937) (traffic stanchion in highway) ; Holl v. Merrill, 251 Wis. 203, 28 N.W. 2d 363 (1947) (condition of county jail causing nuisance on adjacent sidewalk); Hoffman v. Bristol, 113 Conn. 386, 155 Atl. 499 (1931) (public park).

2104 Dillon $\$ 51687$ et seq.; 19 McQuillin $\$ \S 54.01,54.02$.

${ }^{100} \mathrm{La}$ Vigne v. New Haven, 75 Conn. 693, 55 Atl. 569 (1903) ; Hill v. Boston, 122 Mass. 344 (1877); 4 Dillon \$1691; 19 McQuillin \$54.04.

121 A recent collection of these statutes is found in 19 McQuillin $\$ 54.06$.

${ }^{129}$ Consult authorities cited note 118 supra; Warren v. Bridgeport, 129 Conn. 355, 28 A. 2d 1 (1942) (street sweeper); Beckwith v. Stratford, 129 Conn. 506, 29 A. 2d 775 
implied from the power of exclusive control over highways given by the state to the municipality ${ }^{123}$ or, in some cases, the express duty to maintain the highways. ${ }^{124}$ Some states have called the maintenance of highways a corporate function, ${ }^{125}$ but, if the distinction means anything, maintenance of highways is the very prototype of a governmental function. ${ }^{126}$ The rule of liability here must be regarded as an "illogical exception" to the general rule of municipal nonliability for negligence in the performance of governmental duties. ${ }^{127}$ If such an "exception" to an unfortunate "rule" needs justification, it may be found in pragmatic consideration $\mathrm{s}^{128}$ which have been reflected in the well-nigh uni-

(1942) (construction of curbing of sidewalk where crossed by driveway); DeLahunta v. Waterbury, 134 Conn. 630, 59 A. 2d 800 (1948) (traffic stanchion); Jones v. Hayden, 310 Mass. 90, 37 N.E. 2d 243 (1941) (leaving vehicle in dangerous position-not municipality case) ; Robb v. Milwaukee, 241 Wis. 432, 6 N.W. 2d 222 (1942) (maintaining baseball field so as to endanger highway travelers); James, Chief Justice Maltbie and the Law of Negligence, 24 Conn. Bar J. 61 (1950); 19 McQuillin $\$ 54.02$ n. 34.

The nuisance theory is generally available only where the activity or condition (1) injures one in the exercise of a public right, or "in relation to a right which [he] enjoys by reason of his ownership of an interest in land"; (2) is created by the municipality; (3) has at least some continuity. James, op. cit. supra; Brock Hall Dairy v. New Haven, 122 Conn. 321, 189 Atl. 182 (1937) (negligent automobile driving, not nuisance).

There are divergent opinions as to whether the attractive-nuisance doctrine is available to circumvent governmental immunity. Compare Reichvalder v. Taylor, $322 \mathrm{~Pa} .72,185$ Atl. 270 (1936), with Wilson v. Laramie, 65 Wyo. 234, 199 P. 2d 119 (1948).

${ }^{123}$ Paul v. Faricy, 228 Minn. 264, 37 N.W. 2d 427 (1949) (legislative intention to authorize such an action "is inferred when a chartered municipality is given full power of control over the streets and highways within its limits"); Pardini v. Reno, 50 Nev. 392, 263 Pac. 768 (1928); 4 Dillon $\$$ 1708-17; 19 McQuillin $\$ 54.03$.

${ }^{124}$ Consult, e.g., Parmenter v. Marion, 113 Iowa 297, 85 N.W. 90 (1901); 19 McQuillin $\$ 54.03$ n. 28.

${ }^{125}$ Consult, e.g., Missano v. New York, 160 N.Y. 123, 54 N.E. 744 (1899) ; Hewitt v. Seattle, 62 Wash. 377, 113 Pac. 1084 (1911).

${ }^{120}$ See Wilson v. Laramie, 65 Wyo. 234, 243, 199 P. 2d 119, 121 (1948); note, 120 A.L.R. 1376, 1381 (1939) ; Borchard, op. cit. supra note 2, 34 Yale L. J. 229 (1925).

${ }^{127}$ Lane v. Minnesota State Agr. Soc., 62 Minn. 175, 177, 64 N.W. 382, 383 (1895); Wilson v. Laramie, 65 Wyo. 234, 244, 199 P. 2d 119, 121 (1948); 4 Dillon $\$ 1714 ; 19$ McQuillin $\$ 54.03$.

${ }^{22 s}$ Dillon's judgment is that "the doctrine works well and is just, since no stimulus to the performance of duty is more effectual than the wholesale fear of the verdict of a jury for damages." 4 Dillon $\$ 1714$. McQuillin concludes: "It is fully vindicated by the decisions and has found a firm place as a sound and wholesome rule of law in American jurisprudence." $19 \mathrm{McQuillin} \$ 54.04$.

The admonitory effect of tort liability generally may be subject to question. See James and Dickinson, Accident Proneness and Accident Law, 63 Harv. L. Rev. 769 (1950); text at note 252 infra. In the present situation it will be at its strongest because (a) the pressure of liability is put on the party strategically placed to avoid conditions of danger; (b) other incentives to safety are peculiarly lacking here. The city and its employees do not stand to suffer personal injury or property damage from highway defects. Liability aside, the risk is pretty one-sided. 
versal legislative rejection of the "logical rule."129 The main practical difference today between the New England and the more general rules lies in the strictness with which the courts under the former insist on complete and literal compliance with all statutory conditions. ${ }^{130}$

The state and its subdivisions (e.g., counties) have widely been regarded as immune from liability for defective highway conditions in the absence of a statute imposing such liability. ${ }^{131}$ In states which imply municipal liability, this often means that a plaintiff's chance of recovery depends on whether he was hurt inside or outside the city line-an anomaly which has rarely been justified ${ }^{132}$ and is receding in importance with the growth of statutes imposing liability and the recent judicial trend to minimize the distinctions between municipal and quasicorporations. ${ }^{133}$

The requirements for a recovery against a municipality for injury from a highway defect-whether under a statute creating such liability or under the implication of such liability from the power to control highways-are commonly as follows:

(a) A condition of the highway which renders it unreasonably unsafe for ordinary travel, ${ }^{134}$ or for such other proper use (e.g., children's playing thereon $)^{135}$ as is reasonably to be anticipated.

${ }^{200} 19 \mathrm{McQuillin} \$ 54.06$.

${ }^{130}$ Consult, e.g., the unconscionably narrow decisions cited in note 155 infra; Fabrizi v. Golub, 134 Conn. 89, 55 A. 2d 625 (1947); Schaap v. Meriden, 139 Conn. 254, 93 A. 2d 152 (1952).

131 County of Hedges v. Madison, $6 \mathrm{Ml} .567$ (1844); Borchard, op. cit. supra note 2, 34 Yale L. J. 1, 41, 229 (1924-25) ; Tort Claims against the State of Illinois and Its Subdivisions, 47 Nw. U. L. Rev. 914 (1953) ; 4 Dillon § 1688; 19 McQuillin § 54.01.

${ }^{132}$ Dillon thought that there "may be after all ... a substantial difference not readily perceived" in the greater efficiency of cities, so that the distinction was "easier to feel than to unfold and define," 4 Dillon $\$ 1716$, but either this has been too nebulous for most critics, or their feelings led them to a different conclusion. See Borchard, op. cit. supra note 2, 34 Yale L. J. 229, 230 (1925); Tort Claims against the State of Illinois and Its Subdivisions, $47 \mathrm{Nw}$. U. L. Rev. 914, 921 (1953); $19 \mathrm{McQuillin} \$ 54.01$ ("The reason for the distinction between municipal corporations and quasi-municipal corporations, in this respect, has never been satisfactorily explained"). Compare authorities cited note 38 supra.

${ }^{233}$ Consult authorities cited note 38 supra.

I34 4 Dillon $\$ 1694 ; 19$ McQuillin $\$ 54.60$.

${ }^{235}$ Chicago v. Keefe, 114 III. 222, 2 N.E. 267 (1885) ; Schmit v. Cold Spring, 216 Minn. 465, 13 N.W. 2d 382 (1944); cf. Sedita v. Steinberg, 105 Conn. 1, 134 Atl. 243 (1926).

A few states, however, exclude the child at play from the category of highway traveler. Blodgett v. Boston, 90 Mass. 23 (1864). 19 McQuillin $\$ 54.52$ (noting this as minority rule). Cf. Wershba v. Lynn, 324 Mass. 327, 86 N.E. 2d 511 (1949) (man sitting in parked automobile in front of own shop not a traveler). Even under this rule a person does not 
Whether the condition which causes injury is a defect in this sense is usually a question of fact under all the circumstances. ${ }^{136}$ The widest variety of conditions may be defects such as obstructions, ${ }^{137}$ pitfalls, ${ }^{138}$ the presence of snow or ice, ${ }^{139}$ or the want of railings or other guards. ${ }^{140}$ Among the circumstances to be considered are the amount and type of travel to be expected, the general nature of the locality, and the time of year. As the Connecticut court said, "[i]t depends on a great variety of circumstances, which it is impracticable to group together into a legal proposition. A better and safer condition of roads may reasonably be expected and required in the summer than in spring or winter; in populous cities than in unfrequented districts. Much may depend upon the means at command, upon general usage, upon the question whether the defect is the result of a sudden accident or has been long neglected. "1141

The defect may be a result of the plan or design under which the highway was constructed or repaired, ${ }^{142}$ although some courts refuse to impose liability if the plan has been adopted in the good-faith exercise of judgment as long as "reasonable men might differ as to which plan should have been adopted."143

Occasional holdings have excluded liability as a matter of law for "minor defects," such as an obstruction two or three inches above the sidewalk level, or a hole of similar depth. ${ }^{144}$ This represents the adoption of fixed standards of conduct in a way that is generally disappear-

necessarily cease to be a traveler simply because he pauses momentarily, as to look at a store window. Hunt v. Salem, 121 Mass. 294 (1876).

${ }^{130}$ Congdon v. Norwich, 37 Conn. 414 (1870) ; Loughran v. New York, 298 N.Y. 320, 83 N.E. 2d 136 (1948); Maloney v. Grand Forks, 73 N.D. 445, 15 N.W. 2d 769 (1944); 19 McQuillin $\$ \$ 54.60,54.204$.

${ }^{135}$ Representative cases are cited in $19 \mathrm{McQuillin} \$ \$ 54.62,54.63,54.76,54.82$.

${ }^{132} \mathrm{Ibid}$., at $\$ \S 54.75,54.83,54.88$. Cf. authorities cited notes 144 and 145 infra.

${ }^{139}$ Congdon v, Norwich, 37 Conn. 414 (1870); Williams v. New York, 214 N.Y. 259, 108 N.E. 448 (1915); 19 McQuillin $\$ \$ 54.79,54.84,54.89$.

${ }^{360}$ Stevens v. Boxford, 92 Mass. 25 (1865); Widham v. Brattleboro, 105 Vt. 210, 166 Atl. 22 (1933). But cf. Monk v. New Utrecht, 104 N.Y. 552, 11 N.E. 268 (1887).

${ }^{141}$ Congdon v. Norwich, 37 Conn. 414, 418 (1870); Maloney v. Grand Forks, 73 N.D. 445,15 N.W. 2 d 769 (1944).

${ }^{112}$ See text at pp. 627-28 supra.

${ }^{163}$ Consult authorities cited note 112 supra.

14 See, e.g., Lalor v. New York, 208 N.Y. 431, 102 N.E. 558 (1913), which has been credited with the paternity of the "four inch" rule formerly obtaining in New York. Note, 15 Brooklyn L. Rev. 318 (1949); Lindemeyer v. Milwaukee, 241 Wis. 637, 6 N.W. 2d 653 (1942) (waterworks cock box protruding $24^{\prime \prime}$ above surface of walk). 
ing from our law. The persistence of such vestigial rulings in this area is an indication of judicial reluctance to impose liability on cities. Some courts have rejected such a mechanical rule. ${ }^{145}$

To be a defect, the condition need not be within the traveled or paved portion of the roadway. Liability will be imposed if it is an unreasonable threat to some of the reasonably foreseeable incidents of travel. ${ }^{146}$ Moreover, a road or sidewalk may be unsafe because of the dangerous proximity of an excavation or other danger outside the highway limits, unless reasonable precautions (e.g., a fence or barrier) are taken to prevent injury. ${ }^{147}$

(b) The municipality must have had knowledge of or reasonable means of learning about the defect, long enough before the accident so that by exercising due care it could have remedied the defect. ${ }^{148}$ The municipality's duty is not to assure the absence of highway defects, but simply to use due care to prevent or remedy them. If the defect has been created by the municipality this requirement is met, without more. But in the commoner case where the defect is due to natural causes, or disrepair, or the act of a third person, the plaintiff must show (1) either that the city knew of the defect, or would have known of it if it had made the kind of inspection reasonable care required, ${ }^{149}$ and $(2)$

${ }^{125}$ Linn v. Hartford, 135 Conn. 469, 66 A. 2d 115 (1949); Loughran v. New York, 298 N.Y. 320,83 N.E. $2 d 136$ (1948) (repudiating "four inch" rule).

For a general treatment of the recession of fixed standards of conduct (i.e., prescribed by the court as matter of law), consult James and Sigerson, Particularizing Standards of Conduct in Negligence Trials, 5 Vand. L. Rev. 697 (1952). Compare note 112 supra.

${ }^{166}$ E.g., Elliott v. District of Columbia, 160 F. 2d 386 (App. D.C., 1947); Perrotti v. Bennett, 94 Conn. 533, 104 Atl. 890 (1920); Birch v. Charleston Light, H., \& P. Co., 113 IIl. App. 229 (1903); Oklahoma City v. Marshall, 197 Okla. 302, 169 P. 2d 1020 (1946).

${ }^{167}$ E.g., Smith v. Milford, 89 Conn. 24, 92 Atl. 675 (1914); Ollgaard v. Marshall, 208 Minn. 384, 294 N.W. 228 (1940). Consult 19 McQuillin \$ 54.69.

148 McQuillin $\$ 54.102$.

${ }^{110}$ Knowledge may be evidenced by showing that the condition was pointed out to a city employee having the duty to report it (e.g., policeman assigned to beat where defect was); that the city had taken some steps indicating knowledge of the defect, etc., see Weed v. Balston Spa, 76 N.Y. 329 (1879) (village trustee); Pace v. Webster, 138 Iowa 107, 115 N.W. 888 (1908) (street commissioner). Reasonable means of knowledge is commonly evidenced by showing that the defect was obvious or reasonably discoverable and that it had existed for a long enough period of time so that it should have been discovered if the city had been reasonably vigilant. Consult, e.g., cases cited note, 13 A.L.R. 2d 922, 933 (1950); and, on the general problems of proof in similar situations, James, Proof of the Breach in Negligence Cases, 37 Va. L. Rev. 179, 190-93 (1951). Cf., e.g., Ledbetter v. Great Falls, 123 Mont. 270, 213 P. 2d 246 (1949) (issuance of permit for excavation near sidewalk charges city with notice that condition may become dangerous for want of lights, barriers, etc.); and consult note, 13 A.L.R. 2d 922 (1950). 
after this actual or constructive knowledge it had an opportunity to remedy or repair the defect by the exercise of care which was reasonable under all the circumstances. ${ }^{150}$ These will include the nature of the problem facing the city, the means at hand, what is usual and customary, and the like. ${ }^{151}$ If a storm causes widespread conditions of danger, for example, a city can hardly be expected to remedy any given defect as quickly as under normal conditions. ${ }^{152}$ (3) The defect must be the proximate cause of plaintiff's injury. ${ }^{153}$ For the most part the same rules are applied here as elsewhere..$^{154}$ But in Connecticut and Massachusetts the courts have added the unfortunate gloss that the defect must be the sole proximate cause of the injury, so that the town is not liable if a third person's negligence concurred with the defect to cause the damage. ${ }^{155}$ (4) The plaintiff's injury must be special or individual in the sense that it is different from the general public inconvenience caused by defective highways. ${ }^{156}$ In the usual case of personal injury or death or physical property damage, there is no question on this score. (5) Special statutory conditions must be met, such as the giving of written notice of the occurrence of injury within a short period after the accident. ${ }^{157}$ Such a notice of injury is to be distinguished from the constructive notice of the defect which the municipality must have had before the accident. An occasional statute, however, has conditioned liability on written notice of the defect within a specified time before the accident. ${ }^{158}$

\footnotetext{
${ }^{150}$ This is well illustrated by snow and ice cases where the city usually knows of the dangerous conditions while they are being created, yet where the city will be held only after a reasonable opportunity to remove or otherwise remedy the condition. Authorities cited note 139 supra; 19 McQuillin $\$ \$ 54.113,54.114$. Compare Ehrmann v. New York, 273 App. Div. 818, 76 N.Y.S. 2d 53 (2d Dep't, 1948), aff'd 298 N.Y. 685, 82 N.E. 2d 584 (1948).

${ }^{101}$ Cases cited note 141 supra.

${ }^{162}$ See Ehrmann v. New York, 273 App. Div. 818, 76 N.Y.S. 2d 53 (2d Dep't, 1948),
} aff'd 298 N.Y. 685, 82 N.E. 2d 584 (1948) (1944 hurricane).

${ }^{203} 19 \mathrm{McQuillin} \$ 54.144$.

${ }^{15 s}$ Consult James and Perry, Legal Cause, 60 Yale L. J. 761 (1951), and authorities there cited, at 762 n. 4.

155 Bartram v. Sharon, 71 Conn. 686, 43 Atl. 143 (1899); Hayes v. Hyde Park, 153 Mass. 514, 27 N.E. 522 (1891). These rules persist. Fabrizi v. Golub, 134 Conn. 89, 55 A. 2d 625 (1947); Caissie v. Cambridge, 317 Mass. 346, 58 N.E. 2d 169 (1944); Coyne v. Arlington, 327 Mass. 233, 97 N.E. 2d 739 (1951).

${ }^{258} 19$ McQuillin $\$ 54.59$.

${ }^{157}$ Such a requirement is well-nigh universal. Consult 38 Am. Jur., Municipal Corporations $\$ 673$ (1941).

${ }^{258}$ See McMullen v. Middletown, 187 N.Y. 37, 79 N.E. 863 (1907). Consult note, 83 A.L.R. 288 (1933). 


\section{Tort LIability of Public Officers}

The Anglo-American tradition did not include a general theory of immunity from suit or from liability on the part of public officers. ${ }^{159}$ It was the boast of Dicey, often quoted, that "[w]ith us every official, from the Prime Minister down to a constable or a collector of taxes, is under the same responsibility for every act done without legal justification as any other citizen." ${ }^{160}$ of course a statute, or a regulation, or court process might authorize an officer to do an act which would otherwise be a trespass or other wrong, such as the seizure or destruction of property or the arrest of a person. And if the officer could show that he acted in obedience to such authority, that would be a justification for the injury, ${ }^{161}$ at least where the statute or order or process was itself valid. Otherwise he was liable in very much the same way as a private individual, including the employee of a private business, would be. Thus where an officer, authorized by statute to seize undried leather, mistakenly but in good faith seized what turned out to be dried leather, he was liable as a trespasser. ${ }^{162}$

\footnotetext{
${ }^{250}$ Compare Mostyn v. Fabrigas, Cowp. 161 (K.B., 1774), with Moyer v. Peabody, 212 U.S. 78 (1909).

In Ashby v. White, 2 Ld. Raym. 938, 6 Mod. 45 (K.B., 1703), three judges of the King's Bench (Gould, Powys, and Powell) were "against the plaintiff" in an action for damages against an election official for refusing to allow plaintiff, a qualified elector, to vote at an election for burgesses of parliament. But "Holt, Chief Justice, totis viribus for him." 6 Mod. 45. Both reports note that the defendant's judgment was reversed by the House of Lords.
}

${ }^{100}$ Dicey, Law of the Constitution 193 (9th ed., 1939).

10r Mechem, Law of Public Offices and Officers $\$ 661$ (1890) (hereafter cited as Mechem); Harper, Law of Torts $\$ 298$ (1933); Prosser, Torts $\$ 25$ (1941).

For general treatments of the tort liability of public officers, see Jennings, Tort Liability of Administrative Officers, 21 Minn. L. Rev. 263 (1937); David, The Tort Liability of Public Officers, 12 So. Calif. L. Rev. 127, 260, 368 (1938-39); Keefe, Personal Tort Liability of Administrative Officials, 12 Fordham L. Rev. 130 (1943); note, Tort Liability of Administrative Officers in New York, 28 St. John's L. Rev. 265 (1954); Davis, Administrative Law $\$ 231$ (1951); Gelihorn, Administrative Law Cases and Comments 279-310 (1940); Gellhorn and Byse, Administrative Law Cases and Comments 347 (1954).

${ }_{102}$ Warne v. Varley, 6 Term R. 443 (K.B., 1795). This case is not unlike the famous American case of Miller v. Horton, 152 Mass. 540, 26 N.E. 100 (1891), in which a health officer was held liable for destroying a horse which the board of health found diseased but which a jury later found not diseased. The Massachusetts statute involved provided neither for a hearing nor for compensation (in the event of mistake or otherwise). The English statute [2 Jac. I, c. 22 (1604)] provided for a seizure of undried leather by searchers and then a determination of its condition by a board of expert triers. According to the pleadings (the case arose on demurrer) defendants (searchers) acted upon their good judgment but the triers found the leather dried, as in fact it was. The leather was returned to plaintiff and the action was for the seizure and detention. Defendants argued that they were under $a$ statutory duty to act and were subject to statutory 
Generally a government officer is not vicariously responsible for the acts of his subordinates ${ }^{163}$ any more than a foreman or factory superintendent would be, though there is an exception-now possibly losing ground-in the case of sheriffs, marshals and constables who are liable for the acts of their deputies. ${ }^{164}$

1. Special Problems of Officers' Liability. While the liability of the individual officer was said to be like that of "any other citizen," the fact that defendant was acting as a public officer or employee when he caused the injury may inject special problems into the situation that are absent in the case of an employee of private enterprise. These should first be noted, and then the special legal rules that more or less reflect them should be examined.

(a) In some circumstances suit against an officer will in reality be a suit against the state, so that its allowance would circumvent the state's own immunity. This may be the case where the action is one to compel the officer to perform specifically plaintiff's contract with the government $t^{165}$ or to gain possession of property held by the officer on

penalties if they refused to seal dried leather, or sealed undried leather; that the statute contemplated the seizure of suspicious or doubtful (as well as undried) leather to protect the public interest and provided quick expert determination of the facts to protect the owner against everything but a trivial delay. The plight of the officer and the stifling inhibitory effect of strict liability were ably stressed in argument. The judgment of Ashhurst, J., briefly sums up the reasoning and conclusion of the court: "This seems to be a harsh proceeding against the defendants. They are bound to act under the terrors of a penalty; and it is hard that they should be liable in an action of trespass for a mere error in judgment; but the Legislature have not provided for such a case. The Act of Parliament only authorises the searchers to seize goods of a certain denomination; the goods in question are not of that description; therefore the seizure is illegal, and consequently the defendants are trespassers."

Miller v. Horton, supra, is analyzed and commented upon in all the authorities cited note 161 supra. Consult Schwartz, 250 et seq.

${ }^{203}$ Robertson v. Sichel, 127 U.S. 507 (1888); Bowden v. Derby, 97 Me. 536, 55 Atl. 417 (1903); Keenan v. Southworth, 110 Mass. 474 (1872); Dowler v. Johnson, 225 N.Y. 39,121 N.E. 487 (1918); Mechem \$ 789.

While the superior is not vicariously liable for the acts of subordinates, he may be liable for his own negligence, e.g., in failing to control acts done by a subordinate in his presence, Dowler v. Johnson, supra, or in selecting or retaining unfit subordinates (unless that is regarded as a discretionary act). Fernelius v. Pierce, 22 Calif. 2d 226, 138 P. 2d 12 (1943); see Betts v. Jones, 203 N.C. 590, 166 S.E. 589 (1932). But cf. Moye v. McLawhorn, 208 N.C. 812, 182 S.E. 493 (1935), noted in 14 N.C. L. Rev. 307 (1936).

1st "[T] he high-sheriff and under-sheriff is one officer." Cremer v. Humberston, 2 Keble 352 (K.B., 1644) ; Coverstone v. Davies, 227 P. 2d 300 (Calif. App., 1951), rev'd on other grounds 38 Calif. 2d 315, 239 P. 2d 876 (1952), typify the older view. Consult David, op. cit. supra note 161, at 140-41; Mechem $\$ \$ 797-801$. Contrast Michel v. Smith, 188 Calif. 199, 205 Pac. 113 (1922) (police officer not liable for subordinate's act, but case of sheriff and deputy distinguished); note, 25 So. Calif. L. Rev. 382 (1952).

${ }^{185}$ See Lincoln Electric Co. v. Knox, 56 F. Supp. 308, 309 (D.C., 1944). In Larson v. Domestic \& Foreign Corp., 337 U.S. 682 (1949), the Court held that a suit to obtain a 
the government's behalf. ${ }^{166}$ It would seldom, if ever, be the case if the action is to recover tort damages out of the officer's own pocket.

(b) Suit against an officer may have the effect of directly controlling, restraining, or inhibiting governmental action. This will be true where the court is asked to compel or restrain official action. Such a situation involves problems of the proper relationship between the courts and other branches of the government, but a case of such direct (as distinguished from indirect) control or interference is rarely presented by tort suit against an officer.

(c) The private citizen has a very limited duty to act affirmatively so that he is legally free to avoid many tort risks by non-action. ${ }^{167}$ The public officer, on the other hand, is often under a duty to take affirmative action in the public interest, and this duty is apt to be implemented by strong legal ${ }^{168}$ or political sanctions. This difference is often noted ${ }^{169}$ but its practical significance may not be as great as the frequent mention of it suggests. The individual citizen, acting on his own, is driven by strong economic and social sanctions to undertake all sorts of risk-producing endeavors, and we are inclined to welcome rather than deplore that fact. Moreover, the employee of private business is often under a very specific and direct (and sometimes legal) pressure to enter into affirmative activities.

(d) Where fault is a criterion of liability, an action to enforce liability against an officer will often involve the court in a review of the propriety of legislative or executive action, since recovery would turn on a determination whether the official action involved something like an unreasonable mistake. Although a decision that it did would not entail direct interference with governmental action (as in the case of injunction or mandamus), yet both the decision and review would

decree restraining a government officer from selling to others government coal which plaintiff claimed had been sold to it was held to amount to a suit against the government.

${ }^{100}$ Mine Safety Appliances Co. v. Forrestal, 326 U.S. 371 (1945), dealt with critically in Block, Suits against Government Officers and the Sovereign Immunity Doctrine, 59 Harv. L. Rev. 1060 (1946).

The fact that the Larson and Mine Safety Appliances Co. decisions are controversial (consult also Davis, op. cit. supra note 161, $\$ 232$ ) does not concern the problems treated here.

${ }^{107}$ Consult, e.g., Bohlen, The Moral Duty To Aid Others as a Basis of Tort Liability, $56 \mathrm{U}$. of $\mathrm{Pa}$. L. Rev. 217, 289 (1908); McNiece and Thornton, Affirmative Duties in Tort, 58 Yale L. J. 1272 (1949); James, Scope of Duty in Negligence Cases, $47 \mathrm{Nw}$. U. L. Rev. 778 (1953).

${ }^{108}$ Note the officer's predicament in Warne v. Varley, 6 Term R. 443 (K.B., 1795), note 162 supra. Consult Mechem \$ 661 .

${ }^{100}$ Consult, e.g., Jennings, op. cit. supra note 161, at 266, 267; Schwartz 264. 
often involve the courts in conflicts with coördinate branches of the government ${ }^{170}$ and in types of inquiry which they are not accustomed or particularly well suited to make. ${ }^{171}$ This opens up the controversy over the desirable extent of judicial review of the substance of legislative or executive action. Considerations under the present head generally parallel those involved when direct interference with official action is sought, though the conflict here is perhaps less acute. Moreover, there may be situations where the courts are willing to review executive action, but not to stop it in its tracks. ${ }^{172}$

In situations where the government itself is liable on a risk theory (as in eminent domain) to those injured as a by-product of proper as well as mistaken governmental action, the present problem would be minimized. ${ }^{173}$

(e) Under a system of governmental immunity from tort liability, the practical impact of personal liability on a government officer is very different from its impact on a private employee. To be sure, the private master's vicarious liability is theoretically secondary to the servant's direct liability, so that the master has an action over against the "wrongdoing" servant. But by and large this is pure academic theory. The master does not pursue such actions; private enterprise may redistribute its losses on this score but it does not shift them back to individual employees who cause accidents. ${ }^{174}$ The public employee, on the other hand, must bear alone the full weight of the losses he causes unless some provision is made to protect him by insurance, or to re-

${ }^{270}$ Cooley, Torts 377 (1st ed., 1880) ( $\$ 298$ of 4th ed., 1932); Mechem $\$ 609$; compare Jennings, op. cit. supra note 161, at 309; Schwartz 257 ("Under the doctrine of the separation of powers as applied in France the law courts may not question the regularity of administrative acts"); Street 74 (in France even the administrative court, Conseil d'Etat, has retained a doctrine of immunity for actes de gouvernement and "[m]ost French jurists would support the continuance of actes de gouvernement in a restricted form on the ground that it is a necessary condition of harmony between the Administration and the Judiciary; without it droit administratif would be intolerable to the Government").

${ }^{171}$ Consult Jennings, op. cit. supra note 161 , at 275 . The examples of action given in the text at notes 187-90 infra present this kind of situation.

${ }^{173}$ Larson v. Domestic \& Foreign Corp., 337 U.S. 682 (1949). Cf. Mine Safety Appliances Co. v. Forrestal, 326 U.S. 371 (1945); Yakus v. United States, 321 U.S. 414 (1944) (under provisions of Emergency Price Control Act of World War I).

${ }^{173}$ Tendencies in this direction have been noted in French administrative law dealing with the liability of the state (not of the individual officer who is liable only for fautes personelles). Consult Schwartz 289 et seq.; Street 66 et seq. But compare authorities cited notes 170 supra and 193 infra.

17t Consult note, Government Recovery of Indemnity from Negligent Employees: A New Federal Policy, 63 Yale L. J. 570 (1954). 
imburse him ex gratia from the public till. ${ }^{175}$

The upshot of all this is that personal liability will have a far greater deterrent effect-at least in some situations ${ }^{176}$-on public officers than its shadowy counterpart has on private employees. This has a good and a bad side. On the one hand it will tend to curb high-handed official action and other bureaucratic excesses. ${ }^{177}$ On the other, it will often inhibit objective and fearless action and discourage responsible men from taking public employment. ${ }^{178}$

The absence of the government's vicarious liability also means little assurance of recovery to the victim of injurious official action. Since neither his master nor his supervisor shares the officer's liability, any recovery must come from the financially weakest link in the chain. Such a principle of liability may be likened to an inverted pyramid; from a viewpoint which stresses the importance of compensation and wide distribution of losses among the beneficiaries of the enterprise that causes them, the present system is well-nigh the worst that can be imagined.

All in all, the traditional Anglo-American system of state immunity coupled with the officer's liability may well be appraised in Professor Robson's words:

The liability of the individual official for wrongdoing committed in the course of his duty on which so much praise has been bestowed by English writers, is

\footnotetext{
${ }^{175}$ There are occasional statutes providing that a governmental unit indemnify or purchase liability insurance to protect certain specified classes of public servants. See, e.g., Rittmiller v. School Dist. No. 84, 104 F. Supp. 187 (D. Minn., 1952); Govel v. Board of Education, 267 App. Div. 621, 48 N.Y.S. 2d 299 (3d Dep't, 1944), aff'd 293 N.Y. 928, 60 N.E. 2 d 133 (1944); Warp, op. cit. supra note 84, at 372 .

There are also occasional statutory provisions authorizing a municipality to reimburse specified classes of employees for personal judgments rendered against them because of specified kinds of official activity. See Fuller \& Casner, op. cit. supra note 72 , at 451 et seq.

${ }^{170}$ I have often taken the position that the deterrent effect of tort liability on individuals has been greatly overrated. Consult, e.g., James and Dickinson, Accident Proneness and Accident Law, 63 Harv. L. Rev. 769 (1950). With respect to individual conduct in an accident, or other crisis, situation, I am convinced that is true. Where, however, the action concerned involves a deliberate and thought-out choice (such as that to enter public service, or the typical legislative or administrative decision), the case probably stands quite differently (as the text assumes). Consult text at p. 652 infra.

${ }^{177}$ Laski, Responsibility of the State in England, 32 Harv. L. Rev. 447, 458 (1919); Jennings, op. cit. supra note 161, at 270 ; Schwartz 264, 265. But compare Gellhorn, op. cit. supra note 161, at 300 (suggesting that "the chief difference between" courts and administrative tribunals in this respect "is, perhaps, that the possibility of such oppression is frequently mentioned in connection with the administrative tribunals, while the possibility of oppression in courts is conventionally ignored").
}

${ }^{178}$ This is conceded by all hands. Schwartz 263; Street 15. 
essentially a relic from past centuries when government was in the hands of a few prominent, independent and substantial persons, so-called Public Officers, who were in no way responsible to ministers or elected legislatures or councils. . . . Such a doctrine is utterly unsuited to the twentieth-century state, in which the Public Officer has been superseded by armies of anonymous and obscure civil servants, acting directly under the orders of their superiors, who are ultimately responsible to an elected body. The exclusive liability of the individual officer is a doctrine typical of a highly individual common law. It is of decreasing value today. 170

2. Special Rules Governing Officers' Liabilities. The problems and considerations just described have left their mark on the rules governing the liability of officers. The courts have tended in recent years to build up a larger and larger area of privilege or immunity for the officer with respect to his official conduct. It remains to examine these rules.

(a) Suit against the officer will sometimes be regarded as one against the state, ${ }^{180}$ a notion which may affect the court's jurisdiction as well as the officer's liability. This rule has little application to the tort damage suit against an officer, and need not concern us here.

(b) In order to prevent direct interference by the courts with action by coördinate branches of the government, a doctrine has developed that injunction or prerogative writ will not issue to compel or forbid a public officer to do an act which by constitution or statute is discretionary, or to act in any certain way when the law gives him discretion as to the means. ${ }^{181}$ If, on the other hand, the law commands or forbids the officer to do that act, then his function with regard to it is ministerial and his duty will be enforced by appropriate court process. ${ }^{182}$

(c) The most important limitation upon the tort liability of public officers in America today is unfortunately couched in the same terms as the very different rule (just described) governing the issuance of an injunction or prerogative writ. Where official action or non-action involves the exercise of discretion, and is not merely ministerial, the officer is not liable for the injurious consequences of that action even if it was taken negligently or (under some decisions) maliciously; where the action is ministerial only, the officer will be liable if it is otherwise tortious and not justifiable as commanded by valid statute,

\footnotetext{
${ }^{172}$ Robson, Report of the Committee on Ministers' Powers, 3 Pol. Sci. Q. 346, 357-58 (1932), quoted in Gellhorn, op. cit. supra note 161, at 298-99.

${ }^{180}$ Larson v. Domestic \& Foreign Corp., 337 U.S. 682 (1949); Mine Safety Appliances Co. v. Forrestal, 326 U.S. 371 (1945).

182 Mechem $\$ \$ 945,990,991$; Davis, op. cit. supra note 161, $\$ 222,223$.

${ }^{182}$ Mechem $\S \S 937,995-98$; Davis, op. cit. supra note 161, $\$ 222,223$.
} 
order, etc. ${ }^{183}$ This broad privilege for discretionary or quasi-judicial acts was developed in actions against judicial officers ${ }^{184}$ but has been extended by the weight of American case law to legislative ${ }^{185}$ and a host of administrative ${ }^{186}$ officers. The two main groups of considera-

${ }^{188}$ This distinction is noted in all the authorities cited in note 161 supra. Consult also Harper, Law of Torts $\$ 298$ (1933).

${ }^{184}$ Bradley v. Fisher, 80 U.S. 335 (1871), is the leading case. Consult Davis, op. cit. supra note 161, at 801 . But see Picking v. Pennsylvania R.R. Co., 151 F. 2d 240 (C.A. 3d, 1945) (judge may be liable under Civil Rights Act), noted in 46 Col. L. Rev. 614 (1946). The Picking case is of doubtful authority. Tenney v. Brandhove, 341 U.S. 367 (1951); Francis v. Crafts, 203 F. 2d 809 (C.A. 1st, 1953).

${ }^{185}$ Jennings, op. cit. supra note 161 , at $274 ;$ Mechem c. 5 . The immunity extends to legislators of all grades-e.g., members of boards of supervisors, city councils, etc. Jones v. Loving, 55 Miss. 109 (1877).

${ }^{186}$ The immunity was early extended to cabinet officers. Kendall v. Stokes, 44 How. (U.S.) 87 (1845) (Postmaster General); see also Spalding v. Vilas, 161 U.S. 483 (1896) (same); Mellon v. Brewer, 18 F. 2d 168 (App. D.C., 1927) (Secretary of Treasury); Glass v. Ickes, 117 F. 2d 273 (App. D.C., 1940) (Secretary of Interior).

The following list of fairly recent federal cases indicates something of the modern sweep of the rule. Yaselli v. Goff, 12 F. 2d 396 (C.A. 2d, 1926), aff'd [on authority of Bradley v. Fisher, 80 U.S. 335 (1871)] 275 U.S. 503 (1927) (Special Assistant U.S. Attorney sued for malicious prosecution); Brown v. Rudolph, 25 F. 2d 540 (App. D.C., 1928) (Commissioners of D.C. sued for wrongful commitment of plaintiff on their mistaken determination of insanity); Standard Nut Margarine Co. v. Mellon, 72 F. 2d 557 (App. D.C., 1934) (Sec. Treas., Ass't Sec. Treas., Dep. Comm'r of I.R. sued for arbitrarily, capriciously, and maliciously taxing plaintiff's product as margarine and requiring license); Smith v. O'Brien, 88 F. 2d 769 (App. D.C., 1937) (slander action against Chairman of FTC) ; Long v. Wood, 92 F. 2d 211 (App. D.C., 1937) (Atty. Gen., members of U.S. Parole Board, Parole Executive, Warden, Director of Prisons sued for "illegally, maliciously, feloniously, and arbitrarily" revoking plaintiff's parole); Phelps v. Dawson, 97 F. 2d 339 (C.A. 8th, 1938) (fire marshal sued for malicious prosecution of plaintiff for arson); Cooper v. O'Connor, 99 F. 2d 135 (App. D.C., 1938) (Comptroller of Currency and deputies, receiver of bank, attorney for government, special agent of FBI, sued for malicious prosecution); Jones v. Kennedy, $121 \mathrm{~F}$. 2d 40 (App. D.C., 1941) (members and employees of SEC sued for maliciously refusing to allow plaintiff to withdraw its application for registration and pursuing investigation); Laughlin, v. Rosenman, 163 F. 2d 838 (App. D.C., 1947) (confidential assistant to President, Attorney General, special assistant to U.S. Attorney, warden sued for malicious prosecution and procuring of false testimony); Gibson v. Reynolds, 172 F. 2 d 95 (C.A. 8th, 1949) (members of local draft board, Selective Service Appeal Board, State Director of Civil Service and assistant sued for illegal and arbitrary classification of draftee).

Other lists appear in Cooper v. O'Connor, supra, at 141; Phelps v. Dawson, supra, at 340-41; Gibson v. Reynolds, supra, at 98 ; Davis, op. cit. supra note 161, at 803 .

From these cases it is a fair inference that it is not the dignity of high office that is the touchstone of immunity, but rather the nature of the function exercised. Presumably the President would be liable as any other citizen for negligent automobile driving.

One line of state cases holds the function of road supervisors, etc., discretionary with regard to repairing highways. Stevens v. North States Motor, Inc., 161 Minn. 345, 201 N.W. 435 (1925) ; Hip v. Ferrall, 173 N.C. 167, 91 S.E. 831 (1917); Binkley v. Hughes, 168 Tenn. 86, 73 S.W. 2d 1111 (1934). But cf. Ham v. Los Angeles County, 46 Calif. App. 148, 189 Pac. 462 (1920). 
tions $^{187}$ upon which such a rule and its extension are to be justified differ from each other, though they partially overlap. The dangers of confusion inherent in such a situation are obvious-especially where the terminology associated with the rule is also freely used as a guide for applying other rules which involve some but not all of these considerations. ${ }^{188}$ Careful examination is therefore in order.

Where the suit calls upon the courts to review the propriety of legislative or administrative action, questions of the proper relationship between coördinate branches of government are encountered. This occurs most clearly where the official action is legislative or political in character, or where it is regulatory action in which the officer must make a decision in much the same way as a judge or jury does. Thus the legislator who casts the deciding vote for the imposition or repeal of a tariff or other tax is not liable to one injured by the action, in part at least because the courts will refrain from passing judgment on whether the action should be regarded as an unreasonable mistake or even as a mistake at all. ${ }^{189}$ The same thing would be true of an administrative decision (authorized by law) to fix a tariff rate, or the support price for an agricultural commodity, or to ration stoves during wartime. ${ }^{100}$ Similar situations are presented by a decision to enter into a given flood-control project, ${ }^{101}$ or to erect an army camp. ${ }^{102}$ Moreover, the basis for judicial unwillingness to review such actions would exist fully as much in situations where damages are sought directly against the state as where damages are sought against the officer. ${ }^{193}$

\footnotetext{
${ }^{157}$ In addition to them the policy of repose is occasionally suggested. See Bradley v. Fisher, 80 U.S. 335,349 (1871); Street 41 ("it is contrary to public policy that litigants should reopen suits by bringing personal actions against [those?] deciding them"). See Jennings, op. cit. supra note 161, at 271 (reason 5). Where the official action followed a trial or other examination of subject matter in which the present party was a participant (as in Bradley's case) this may deserve consideration. In other types of situations this factor is rarely, if ever, mentioned.

${ }_{188}$ Thus there are situations wherein courts are willing to review the propriety of official conduct (because it does not involve discretion), but not to stop it in its tracks.

${ }^{I \infty}$ Suits which would test any such proposition are scarcely ever brought, perhaps because the proposition is scarcely to be doubted. In Jones v. Loving, 55 Miss. 109 (1877), a city councilman was sued because of legislative action which abolished plaintiff's office. Malice was alleged. Plaintiff got short shrift.
}

${ }^{100}$ Cf. Jones v. United States, 89 F. Supp. 980 (S.D. Iowa, 1949); Matveychuck v. United States, 195 F. 2d 613 (C.A. 2d, 1952).

${ }^{201}$ See, e.g., Coates v. United States, 181 F. 2d 816 (C.A. 8th, 1950).

${ }^{102}$ See, e.g., Smith v. United States, 113 F. Supp. 131 (D. Del., 1953).

${ }^{103}$ If, that is, liability is put on a fault basis. If liability were put on a risk basis the present difficulty would not be encountered in the same form although the question would 
Wherever suit is brought against an individual officer because of his official conduct, the court must consider the practical effects of liability and make a value judgment between the social and individual benefit from compensation to the victim, together with the wholesome deterrence of official excess, on the one hand; and on the other, the evils that would flow from inhibiting courageous and independent official action, and deterring responsible citizens from entering public life. The rule of immunity of officers for discretionary acts, and its extension, represent a judgment that the benefits to be had from the personal liability of the officer (especially since the prospect of actual compensation to the victim from that source is slight) are outweighed by the evils that would flow from a wider rule of liability. To the extent that this value judgment is valid, and I believe it is, it is broadly applicable to official conduct, and not merely to situations presenting questions of conflict between coördinate branches of government or the desirable scope of judicial review. There are a good many situations in which the last-mentioned questions are not present, yet where the considerations which call for the personal immunity of the officer-at least if he acts honestly and in good faith-apply fully. For instance, when Fisher sued Judge Bradley ${ }^{194}$ for damages for his allegedly wrongful disbarment, only a single branch of the government was involved in all phases of the matter. Moreover, the courts often interfere with legislative or executive action. They will declare statutes or regulations unconstitutional; they will determine whether a regulation goes beyond the statutory authority claimed to support it; they will decide whether administrative action in specific cases is warranted by what they (the courts) judge to be the proper interpretation of a valid regulation or statute, and sometimes whether administrative findings of fact may be supported. ${ }^{195}$ But if personal liability may be visited upon officers who

remain as to how far society should insure against the injurious consequences of political decisions. And the influence of the administrative branch of the government will probably always be thrown against extending its liability as insurer. Authorities cited note 170 supra.

${ }^{204}$ Bradley v. Fisher, 80 U.S. 335 (1871).

${ }^{100}$ Kendall v. Stokes, 44 How. (U.S.) 86 (1845) (propriety of Postmaster General's refusal to pay claim settled by Solicitor General reviewed on mandamus); Miller v. Standard Nut Margarine Co., 284 U.S. 498 (1931) (propriety of levying tax on plaintiff's product under existing statute reviewed and collection of tax enjoined); Jones $v$. SEC, 298 U.S. 1 (1936) (propriety of refusal to allow withdrawal of application for registration under applicable statute reviewed on resistance to commission's application for order) ; Gibson v. United States, 329 U.S. 338 (1946) (propriety of draftee's classification may be challenged in defense to criminal prosecution under Selective Service Act 
have acted in accordance with their apparent commands and their best judgment in these matters, we are indeed likely to breed a race of donothing officials. The tendency is to protect the officer by regarding his function as quasi-judicial or discretionary. ${ }^{106}$ There is still another class of cases which do not present any acute question of intragovernmental conflict but do call for the officer's immunity from personal liability on the grounds presently under consideration. Governments engage in many projects which involve functions not at all regulatory or political in their nature but calling for the exercise of judgment or discretion by the officials employed to carry them out. In the execution of a floodcontrol project, for example, someone must decide upon the size of the charges to be used in blasting. ${ }^{197}$ If ammonium nitrate on hand after the war is to be shipped abroad for the agricultural rehabilitation of our allies, someone must decide how it is to be prepared and shipped and whether there is need to investigate its dangerous propensities. ${ }^{198}$ If willows in an experimental area are to be eradicated, someone must choose the herbicide and the means of applying it. ${ }^{199}$

While all the types of cases described in the last paragraph involve considerations which would protect the officer from personal liability, it does not follow, nor is it true, that these considerations would be applicable to the same extent if liability were put upon the government rather than the officer. However impolitic it was to make Horton pay for Miller's horse, there may be excellent reasons why the community should pay for it. But more of this later.

The American rule today, then, is that judicial, legislative, and ad-

under certain circumstances); Hicks v. Davis, 97 Kan. 312, 662, 154 Pac. 1030, 156 Pac. 774 (1916) (propriety of auditor's refusal to pay item appropriated by legislature reviewed on mandamus); State ex rel. Roerig v. Minneapolis, 136 Minn. 479, 162 N.W. 477 (1917) (propriety of building inspector's refusal to issue permit for four-family flat in residential area reviewed on mandamus); see Tyrell v. Burke, 110 N.J.L. 225, 227, 164 Atl. 586, 587 (1933) (dictum that mandamus would lie against licensing board for failure to issue license to qualified embalmer and funeral director, if mistakenly denied).

The many and complex conditions sometimes put upon obtaining such review need not detain us here.

${ }^{100}$ This may be dramatically shown by the decisions denying civil recovery against the officers involved in each of the cases cited in note 195 supra. Kendall v. Stokes, 44 How. (U.S.) 86 (1845); Standard Nut Margarine Co. v. Mellon, 72 F. 2d 557 (App. D.C., 1934); Gibson v. Reynolds, 172 F. 2d 95 (C.A. 8th, 1949); Hicks v. Davis, 100 Kan. 4, 163 Pac. 799 (1917) ; Roerig v. Houghton, 144 Minn. 231, 175 N.W. 542 (1919); Tyrell v. Burke, 110 N.J.L. 225, 164 Atl. 586 (1933). Cf. also Jaffarian v. Murphy, 280 Mass. 402, 183 N.E. 110 (1932).

${ }^{10 \pi}$ See Boyce v. United States, 93 F. Supp. 866 (S.D. Iowa, 1950).

${ }^{103}$ See Dalehite v. United States, 346 U.S. 15 (1953).

${ }^{100}$ See Harris v. United States, 205 F. $2 d 765$ (C.A. 10th, 1953) ; 22 Geo. Wash. L. Rev. 496 (1954). 
ministrative officers are not generally liable for the injurious consequences of discretionary action or non-action. ${ }^{200}$ And the tendency has been to define the concept of discretionary or quasi-judicial action broadly in favor of immunity. ${ }^{201}$ Limitations on this rule of privilege or immunity should now be noted.

Two doctrines which are losing favor cut right athwart the reasoning in favor of privilege: the "jurisdictional facts" doctrine and the notion that an unconstitutional statute affords no protection to one acting under it. ${ }^{202}$ The latter doctrine is self-explanatory; the former views the officer's statutory powers as extending to situations wherein the court finds the facts and interprets the statute so that the one fits into the other. An example of such reasoning may be found in Miller $v$. Horton, ${ }^{203}$ described above. It has been perhaps most often used where there was a physical trespass upon property. ${ }^{204}$

Even today if the officer acts clearly outside the authority conferred on him by statute, regulation, or process, he is liable for the injurious consequences of his conduct. "Thus, if a probate court, invested only with authority over wills and the settlement of estates ..., should proceed to try parties for public offenses ...." the judge would be liable. ${ }^{205}$ But the notion today is recognized that an officer generally has the duty and the power to determine whether he has jurisdiction-or, to emphasize it, that he has jurisdiction to determine even mistakenly that he has jurisdiction-unless the facts and the law are so clear as not to present an issue challenging "judicable inquiry."206 And statutes are

\footnotetext{
${ }^{200}$ See Schwartz 254; Davis, op. cit. supra note 161, $\$ 231$; Harper, op. cit. supra note $161, \$ 298$.

201 Cases cited note 196 supra, note 207 infra.

${ }^{202}$ See Rapacz, Protection of Officers Who Act under Unconstitutional Statutes, 11 Minn. L. Rev. 585 (1927); Field, The Effect of an Unconstitutional Statute c. 5 (1935).

${ }^{203}$ Authorities cited note 162 supra.

${ }^{206}$ See the famous statement by Dillon, C. J., in McCord v. High, 24 Iowa 336, 350 (1868) ("The discretion which protects such an officer as the road supervisor stops at the boundary where the absolute rights of property begin").

The cases associated with the doctrine did in fact involve trespasses to property. Warne v. Varley, 6 Term R. 443 (K.B., 1795) ; Miller v. Horton, 152 Mass. 540, 26 N.E. 100 (1891); Lowe v. Conroy, 120 Wis. 151, 97 N.W. 942 (1904). The failure to provide for any hearing and for any alternative means of compensating the victim of official mistake also played a part in Miller v. Horton, supra. See various treatments of case in authorities cited note 161 supra, especially Jennings, at 281 et seq.

${ }^{906}$ Field, J., in Bradley v. Fisher, 80 U.S. 335, 352 (1871). In this case the distinction was formulated as one between "excess of jurisdiction and the clear absence of all jurisdiction over the subject matter," ibid., at 351, and this is the language in which it is usually described.

${ }^{200}$ Consult, e.g., Boskey and Braucher, Jurisdiction and Collateral Attack, $40 \mathrm{Col}$. L. Rev. 1006 (1940).
} 
generally interpreted in the light of this prevailing notion. Today most courts would probably find that Varley was justified in seizing "suspicious" leather and Horton in destroying an apparently infected horse even under the statutes involved in those cases. ${ }^{207}$ There are still situations, however, where the officer acts at his peril, as where a sheriff seizes the property of $B$ reasonably believing it to be the property of $A$ against whom he has a writ of attachment; ${ }^{208}$ or where a fiscal officer invests or expends public funds. ${ }^{209}$ The policies which justify these results are certainly not revealed by terming the officers' acts ministerial, as the courts do.

Most tasks of a clerical ${ }^{210}$ or manual ${ }^{211}$ nature are classed as ministerial though they too involve the exercise of judgment. There is conflict in the cases where the officer is charged with improper motive or malice (yet acts within the scope of his official capacity). Judges are generally protected ${ }^{212}$ and the federal rule extends this protection to administrative officials. ${ }^{213}$ Older state cases also followed this tendency, ${ }^{214}$ but the more recent cases perhaps reveal a trend in the other direction. ${ }^{215}$ The justification for absolute privilege here is obviously not to protect officers who have in fact acted wilfully and maliciously, and if it were possible in practice to bring such complaints only against the guilty, it would be monstrous to deny recovery. The justification for doing so is that it is impossible to know whether the claim is well founded until the case has been

${ }^{20}$ See, e.g., Raymond v. Fish, 51 Conn. 80 (1883); Beeks v. Dickinson County, 131 Iowa 244, 108 N.W. 311 (1906); McGuire v. Amyx, 317 Mo. 1061, 297 S.W. 968 (1927); Valentine v. Englewood, 76 N.J.L. 509, 71 Atl. 344 (1908); Wright v. White, 166 Ore. 136, 110 P. 2d 948 (1941); compare cases cited note 196 supra; Jennings, op. cit. supra note 161, at 291. $\$ 50$.

${ }^{200}$ Buck v. Colbath, 70 U.S. 334 (1865); 47 Am. Jur., Sheriffs, Police, \& Constables

${ }^{200}$ See, e.g., Bird v. McGoldrick, 277 N.Y. 492, 14 N.E. 2d 805 (1938); Keefe, op. cit. supra note 161, at 133 .

${ }^{210}$ Examples are Rising v. Dickinson, 18 N.D. 478, 121 N.W. 616 (1909) (negligent failure by registrar of deed to index a mortgage properly); Johnson v. Brice, 102 Wis. 575, 78 N.W. 1086 (1899) (same).

${ }^{2 n}$ An example is negligence in driving a fire truck. Florio v. Schmolze, 101 N.J.L. 535, 129 Atl. 470 (1925).

${ }^{212}$ Bradley v. Fisher, 80 U.S. 335 (1871); Jennings, op. cit. supra note 161, at 270 et seq.; Davis, op. cit. supra note 161, at 801.

${ }^{213}$ See Gregoire v. Biddle, 177 F. 2d 579 (C.A. 2d, 1949); cases cited note 186 supra, in most of which malice was alleged; Public Officers-Liability of Federal Officers for Quasi-Judicial Acts, 40 Mich. L. Rev. 755 (1942).

${ }^{24}$ Cases are collected in Jennings, op. cit. supra note 161, at 277-78 n. 55. Examples are Stewart v. Case, 53 Minn. 62, 54 N.W. 938 (1893); Steel v. Dunham, 26 Wis. 393 (1870).

${ }^{215}$ Largely by way of dictum. See case collected Jennings, op. cit. supra note 161 , at 278-79 n. 56. An example is Tyrell v. Burke, 110 N.J.L. 225, 164 Atl. 586 (1933). But see 
tried, and that to submit all officials, the innocent as well as the guilty, to the burden of a trial and to the inevitable danger of its outcome, would dampen the ardor of all but the most resolute, or the most irresponsible, in the unflinching discharge of their duties. ${ }^{216}$

The case for conditional privilege is often rested on arguments that assume the presence of malice in the individual case, and so fail to meet Judge Hand's point cleanly; ${ }^{217}$ yet perhaps they suggest a flaw in it in spite of that. Where the charge is one of honest mistake we exempt the officer because we deem that an actual holding of liability would have worse consequences than the possibility of an actual mistake (which under the circumstances we are willing to condone). But it is stretching the argument pretty far to say that the mere inquiry into malice would have worse consequences than the possibility of actual malice (which we would not, for a minute, condone). Since the danger that official power will be abused is greatest where motives are improper, the balance here may well swing the other way.

It is often said that while an official may be held liable for the injurious consequences of misfeasance or malfeasance, liability cannot be grounded on nonfeasance. ${ }^{218}$ Of course, if the officer has discretion to do an act or not, his choice will be protected by the discretion rule. If a distinction in favor of non-action is carried any further than this, it would surely dampen the ardor and initiative of officialdom. Few cases can be found to make the distinction where the choice between action and non-action is regarded as ministerial, and therefore reviewable

Jaffarian v. Murphy, 280 Mass. 402, 183 N.E. 110 (1932) (no damages for mayor's capricious refusal to issue license); Nadeau v. Marchessault, 112 Vt. 309, 24 A. 2d 352 (1942) (no damages for malicious failure of poor overseer to provide food, etc.); Davis, op. cit. supra note 161 , at 804 .

${ }^{20}$ L. Hand, J., in Gregoire v. Biddle, 177 F. 2d 579 (C.A. 2d, 1949).

${ }^{217}$ E.g., the incompatibility between malice and the official character of the determination, Jennings, op. cit. supra note 161, at 279.

${ }^{213}$ See Smith v. Iowa City, 213 Iowa $391,395,239$ N.W. 29, 31 (1931); Moynihan v. Todd, 188 Mass. 301, 74 N.E. 367, 369 (1905) ; Stevens v. Northern States Motor, Inc., 161 Minn. 345, 349, 201 N.W. 435, 436 (1925); Jennings, op. cit. supra note 161, at 267 n. 18, 298-99; Tort Liability of Administrative Officers in New York, 28 St. John's L. Rev. 265,270 (1954).

It should be noted that the usual form of statement compares unlike things. The words misfeasance and malfeasance imply wrongful or tortious action, while nonfeasance is a purely neutral word, so that obviously liability should not (under the fault system) be imposed upon an officer or anybody else for mere nonfeasance. To be meaningful the comparison should be between misfeasance or malfeasance and improper nonfeasance, and if the statement had to be made in that careful way it probably would often not be made at all. 
under the discretion rule. ${ }^{219}$ Some courts repudiate any distinction between misfeasance and (improper) nonfeasance. ${ }^{220}$

\section{Legislative Modifications}

From fairly early times there have been statutes providing for the tort liability of smaller governmental units. Thus the New England states, as we have seen, made their towns liable for defects in town highways. ${ }^{221}$ Several states have provided for the liability of municipal corporations for torts caused by municipally owned vehicles being used to carry out governmental functions. ${ }^{222}$ Some states have provided for liability of school districts (or other quasi-corporations administering education) in the pursuit of various educational activities. ${ }^{223}$ About half our states have statutes making a political subdivision liable for mob violence, ${ }^{224}$ more or less after the manner of the old English Riot Acts. ${ }^{25}$ Other statutes provide a fairly effective substitute for governmental liability by authorizing or requiring a governmental unit to purchase liability insurance either for its own protection or to indemnify its employees for their personal liability. ${ }^{226}$ Except in New York, ${ }^{227}$ there seems to be no statute providing broadly for the tort liability of the political subdivisions of a state.

As to the liability of the state itself, there are several types of provisions. Here again some statutes create liability for torts in connection with certain activities, such as the operation of state-owned motor

${ }^{219}$ Thus the Stevens case dealt with the failure to place warning signs for a dangerous highway condition and Minnesota treats this as a discretionary function. Authorities cited note 186 supra. But an officer is liable for omission to perform a ministerial duty. Howley v. Scott, 123 Minn. 159, 143 N.W. 257 (1913). Compare 4 Dillon $\$ 1645$.

${ }^{200}$ See, e.g., Adams v. Schneider, 71 Ind. App. 249, 258, 124 N.E. 718, 720 (1919); Wright v. Shanahan, 149 N.Y. 495, 502, 44 N.E. 74, 75 (1896); Hale v. Johnston, 140 Tenn. 182, 198, 203 S.W. 949, 952-53 (1918) ; Tort Liability of Administrative Officers in New York, 28 St. John's L. Rev. 265, 272 (1954).

22 Authorities cited note 121 supra.

${ }^{220}$ Schumacher v. Milwaukee, 209 Wis. 43, 243 N.W. 756 (1932); Calif. Vehicle Code (Deering, 1948) $\$ \$ 400,401$; Ohio Gen. Code (Page, 1937) §3714-1.

${ }^{223}$ See, e.g., Briscoe v. School Dist. No. 123, 32 Wash. 2d 353, 201 P. $2 d 697$ (1949); Warp, op. cit. supra note 84 , at 372 .

2s For citations of cases, and statutes, see Warp, op. cit. supra note 84 , at $373-74 ; 18$ McQuillin $\$ \$ 53.145$ et seq.

${ }^{225} 1$ Geo. I, stat. 2 , c. 5 (1714); 9 Geo. I, c. 22 (1722).

${ }^{2}$ See, e.g., Calif. Gov. Code (Deering, 1948) \$1956; Minn. Stat. Ann. (1946) $\$ \S 471.42,471.43 ; 18$ N.J. Stat. Ann. (1939) $\$ 5-50.4$; New York Education Law (1947) $\$ 3023$; authorities cited notes $35,37,175$ supra.

${ }^{22 \pi}$ N.Y. Consol. L. (1954) c. 24, §50(b). Bernardine v. New York, 294 N.Y. 361,62 N.E. 2d 604 (1945); Lloyd, Municipal Tort Liability in New York, 23 N.Y.U.L.Q. Rev. 278 (1948). 
vehicles ${ }^{228}$ or the maintenance of state highways. ${ }^{229}$ Other statutes, of more general application, set up a board to investigate claims and recommend action upon them to the legislature. ${ }^{230} \mathrm{New}$ York has waived immunity broadly and set up a special court to make determinations of liability (under general tort principles) which are binding except as reversed or modified in the course of judicial appeal. ${ }^{231}$ For a brief period (1943-1945) Michigan statutes provided for a waiver nearly as broad. ${ }^{232}$

Within the past decade Congress too, after experimenting with piecemeal legislation of the kind described above, enacted a broad waiver of the immunity of the federal government by the Tort Claims Act of $1946 .^{233}$ This act extends only to claims for money on account of property damage, personal injury, or death

caused by the negligence or wrongful act of any employee of the Government while acting within the scope of his office or employment, under circumstances where the United States, if a private person, would be liable to the claimant for such damage, loss, injury or death in accordance with the law of the place where the act or omission occurred. ${ }^{234}$

${ }^{20}$ E.g., Calif. Vehicle Code (Deering, 1948) § 400; Conn. Gen. Stat. (1949) c. 384, $\$ 7781$, c. $413, \S 8297$.

Summaries of the existing provisions governing state liability in all forty-eight states may be found in Leflar and Kantrowitz, Tort Liability of the States, 29 N.Y.U.L. Rev. 1363 (1954).

$=0$ E.g., Conn. Gen. Stat. (1949) c. 107, §2201.

${ }^{20}$ Such procedures are set up, e.g., in Alabama, Illinois, and West Virginia (see note 28 supra). Short descriptions of them may be found in Bench \& Bar, Claims against the State in Minnesota, 32 Minn. L. Rev. 539 (1948); Anderson, Claims against States, 7 Vand. L. Rev. 234 (1954) (Judge Anderson "has not been able to learn of any case where the General Assembly [of Tllinois] has not followed the recommendations of the court and paid according to its recommendations").

See $\mathrm{Il}$. Rev. Stat. (1949) c. $37, \$ \$ 439.1-.23$; and for a recent venture along this line, Minn. Stat. Ann. (West Supp., 1953) $\$ 3.42$.

Consult comment, Tort Claims against the State of Illinois, 47 Nw. U. L. Rev. 914 (1953).

${ }^{201}$ N.Y. Ct. Claims Act Ann. (Gilbert-Bliss, 1947) $\$ 2$.

See Benson v. State, 316 Mich. 66, 25 N.W. 2d 112 (1946); Minty v. State, 336 Mich. 370, 58 N.W. 2d 106 (1953).

The present statutes waive the defense of governmental function where the operation of state-owned motor vehicles is concerned. Mich. Stat. Ann. (Cum. Supp., 1951) $\$ 27.3548(41)$.

2828 U.S.C.A. $\$ \$ 2671-80$ (1948). Exclusive jurisdiction over actions under this act is vested in the federal district courts. Ibid., at $\$ 1346$ (b). Trial is to be without a jury. Ibid., at $\$ 1346$ (b), 2402 .

For a general discussion of the provisions of the act consult comment, The Federal Tort Claims Act, 56 Yale L. J. 534 (1947).

ssi 28 U.S.C.A. $\$ 1346$ (b) confers jurisdiction on the district courts to hear claims described by the language in the text. Ibid., at $\$ \$ 2672,2674$. 
It will be seen that the statute apparently chooses the fault basis of liability. But it does not embrace the fault principle fully. The Act contains explicit exceptions, of which some exclude even liability for fault in connection with specified activities, ${ }^{235}$ and others exclude liability for certain kinds of faults, such as deliberate torts ${ }^{236}$ and negligence in the exercise of a discretionary function. ${ }^{237}$ The courts have imported still other exceptions into the Act, such as the denial of claims by servicemen injured (by a government tort) in the course of active duty, ${ }^{238}$ of claims by federal prisoners, ${ }^{239}$ and of claims arising out of flood- and river-control projects ${ }^{240}$ or coast-guard activities. ${ }^{241}$ I have recently treated these exceptions in some detail elsewhere. ${ }^{242}$ Here an appraisal will be attempted of the net effect of the Act in terms of the objectives of tort law and the limitations on liability which are peculiarly appropriate when the government is the defendant.

Except possibly for some of the excluded activities, the most important reservation in the Act has turned out to be that contained in Section 2680 (a). ${ }^{243}$ This excludes liability for claims based upon either (1) "the act or omission of an employee ... exercising due care, in the execution of a statute or regulation, whether or not such statute or regulation be valid"; or (2) "the exercise or performance or the failure to exercise or perform a discretionary function or duty on the part of a Federal agency or an employee of the Government, whether or not the discretion be abused."

This section, it is submitted, is an ill-conceived and poorly thoughtout attempt to solve some of the most sensitive problems concerning the proper limits of governmental liability. Apparently the limitations that have developed for the tort liability of public officers were bor-

${ }^{235}$ Tbid., at $\$ 2680$ (b), (c), (e), (f), (g), (i), (j), (l), (m) (miscarriage of mail, assessment or collection of tax, administration of Trading with Enemy Act, Panama Canal operations, fiscal operations, combat activities in wartime, etc.).

${ }^{230}$ Ibid., at $\$ 2680(\mathrm{~h})$. ${ }^{207}$ Ibid., at $\$ 2680$ (a).

${ }^{238}$ Feres v. United States, 340 U.S. 133 (1950).

Sigmon v. United States, 110 F. Supp. 906 (W.D. Va., 1953), noted, 63 Yale I. J. 418 (1954); Shew v. United States, 116 F. Supp. 1 (M.D. N.C., 1953); Van Zuch v. United States, 118 F. Supp. 468 (E.D. N.Y., 1954).

${ }^{280}$ National Mfg. Co. v. United States, 210 F. 2d 263 (C.A. 8th, 1954).

${ }_{201}$ P. Dougherty Co. v. United States, 207 F. 2d 626 (C.A. 3d, 1953), cert. denied 347 U.S. 912 (1954); Seavey, "Liberal Constructions" and the Tort Liability of the Federal Government, 67 Harv. L. Rev. 994 (1954).

${ }^{202}$ See James, Inroads on Old Tort Concepts, prepared as the NACCA lecture for 1954 in the field of Personal Injury (Tort) Law, which will appear in forthcoming issues of the NACCA Law Journal.

${ }^{213}$ At least it is the most litigated. See Shepard's U.S. Citations 1304, 1305 (Supp., 1943-52) and current paper supplement. 
rowed and transplanted bodily into this new and different field. But it would be a surprising thing if rules that developed under the shadow -and in large part because of the shadow ${ }^{244}$ - of governmental immunity would all be suitable under conditions where that shadow has been largely removed. Indeed, where the government is liable the situation has been quite dramatically reversed, by providing in effect that the employee or official is not personally liable at all, ${ }_{2}^{245}$ thus producing a pattern of liability which resembles (in this particular) that obtaining in France for fautes de service. ${ }^{246}$ This does not mean that all the rules of immunity for officers are necessarily unsuitable in the new context, but it does call for a careful appraisal of the extent to which the policies behind them validly support continued governmental immunity.

In the case of officers, we noted that they are immune from liability even for fault in the exercise of discretionary functions. When a legislative or political decision is involved, this immunity is justified in part by a judicial unwillingness to review the propriety of actions which under our form of government are committed to coordinate branches of that government, ${ }^{247}$ and a commendable judicial desire to avoid unseemly intragovernmental conflict. We also observed that the same problem will be present where an attempt is made to predicate the liability of the government itself on fault in the making of such a decision; ${ }^{248}$ and without much doubt the courts would refuse to put liability on such a basis even if the Act were silent on the subject. ${ }^{249}$ Perhaps the second clause of section 2680(a) was not meant to go any further than this; for Congress was told that the section did no more than the courts would probably do without it. ${ }^{250}$ But if this was the intention, it is most unfortunate that language was chosen that had

${ }^{24}$ See pp. 638-47 supra.

${ }^{215}$ United States v. Gilman, 347 U.S. 507 (1954); Government Recovery of Indemnity from Negligent Employees: A New Federal Policy, 63 Yale L. J. 570 (1954).

${ }^{286}$ Schwartz 258 et seq.; Street 16-19.

${ }^{247}$ Consult pp. 637-38, 640 supra. $\quad{ }^{248}$ Consult p. 642 supra.

${ }^{240}$ The New York statute [N.Y. Ct. Claims Act Ann. (Gilbert-Bliss, 1947) $\$ 8$ ] has no such limitation, yet her courts will not hold governmental units for consequences of decisions of a political nature. Murrain v. Wilson Line, 270 App. Div. 372,59 N.Y.S. 2d 750 (1st Dep't, 1946), aff'd 296 N.Y. 845, 72 N.E. $2 d 29$ (1947); cf. Goldstein v. State, 281 N.Y. 396, 24 N.E. 2 d 97 (1939).

See also Dalehite v. United States, 346 U.S. 15, 32 n. 27 (1953) (indicating emergence of such exceptions in British Commonwealth); Street, Tort Liability of the State, 47 Mich. L. Rev. 341, 353 (1949).

${ }^{250}$ Consult statement to this effect by Assistant Attorney General Francis M. Shea before congressional committee. H. Hearings before Comm. on Jud. on H.R. 5373 and H.R. 6463, 77th Cong. 2d Sess. 29 (1942). 
become associated with the law of liability of public officers, for as we have seen the officer is personally immune from liability for negligence in large areas of "discretionary" activity which the courts are perfectly willing and quite competent to review. ${ }^{251}$ Immunity here rests on the entirely different basis that personal liability would keep responsible people from entering public life and would prevent officials from the objective and courageous performance of their functions. It remains to be determined whether these considerations apply to any extent when governmental liability is involved.

It must be admitted at the outset that not nearly enough critical thought, and almost nothing in the way of scientific study, has been given to the deterrent effects of tort liability. ${ }^{252}$ Nevertheless we must try to appraise as well as we may the probable effect of transferring potential liability from the officer to the government. It seems fairly clear that this will at least remove any obstacle which personal liability might put in the way of entering public life. Responsible men are no more unlikely to enter government service than private service because of the fear of their employer's tort liabilities. But that is only part of the story. It is not equally clear that the government's liability might not tend to throttle fearless discretionary action-surely administrators often have a weather eye cocked for the departmental budget. Yet the unwholesome effect of this sort of thing is most pronounced where the decision to be made is of a regulatory or political character, such as a decision of the SEC, or a broad policy decision to enter into a government project, or to locate it in one area rather than another. When it comes to the host of decisions which call for judgment in executing or carrying out these projects (such as the examples given on page 644 above), the effect upon officers of their employer's liability for their negligence might well be a wholesome one tending to make them careful rather than craven. After all, it would only bid them weigh the alternative ways of carrying out the enterprise in very much the same way as employees in private ventures do all the time. There seems, therefore, to be no justification on the present score for exempting government from liability for the negligence of its employees in exercising their judgment, except where the challenged conduct involves a legislative or regulatory decision, or one of broad government policy.

\footnotetext{
${ }_{251}$ Consult pp. 643-44 supra.

${ }^{252}$ For attempts that merely scratch the surface see James, Accident Liability Reconsidered: The Impact of Liability Insurance, 57 Yale L. J. 549 (1948) ; James and Dickinson, Accident Proneness and Accident Law, 63 Harv. L. Rev. 769 (1950). Consult also notes 128 and 176 supra.
} 
The problem of deterrence is presented in a different context by the exclusion of government liability for its employees' deliberate torts. Here, on the whole, deterrence appears in benign garb as a guardian against abuses by officialdom, though the problem gets complex where libel and slander are concerned since inhibitions in that field inevitably curb some freedom of speech. ${ }^{253}$ Matters of speech aside, the pertinent question is whether governmental liability will add to or detract from the wholesome deterrence of personal liability. Even if the government alone were liable, the increased spur to stern discipline over officers might more than offset the increased irresponsibility that would flow from personal immunity-especially since the officer's financial situation is rarely such as to warrant suit against him. But even if that were not so, legislation could easily preserve the officer's primary liability in the case of wilful torts; and a rigorous administrative policy of enforcing such primary liability ${ }^{254}$ would add the force of one deterrent to another.

Even where liability would not be an unwanted deterrence, the question remains of the extent to which it is desirable to compensate out of public funds those injured by what government does in the public interest. The older view chose to sacrifice the individual claim altogether, except within the narrow confines of a taking of property in the constitutional sense. But the whole trend of modern thinking is toward compensating the victims of enterprise and distributing their losses. Even conservatives would do this where the victim is innocent, where his injury is of a kind already recognized in private tort law, and where there is fault in conducting the enterprise. The device of government liability offers machinery for both compensation and distribution; it should be used to compensate the victims of government at least to the full extent of the fault principle except in situations where there are cogent reasons of extrinsic policy for withholding compensation. These reasons exist for legislative and other political decisions, but not elsewhere unless the possible magnitude of claims be thought a reason, as it may have been in the Texas City disaster litiga-

\footnotetext{
203 "Whatever is added to the field of libel is taken from the field of free debate." Edgerton, J., in Sweeney v. Patterson, 128 F. 2d 457, 458 (App. D.C., 1942). See also sources collected in Shulman and James, Cases and Materials on Torts 950-1007 (2d ed., 1952).

${ }^{20 s}$ Such as that apparently pursued just recently by the government in the case of ordinary negligence, with far less (if any) justification. Consult Government Recovery of Indemnity from Negligent Employees: A New Federal Policy, 63 Yale L. J. 570 (1954). Presumably this practice ended with United States v. Gilman, 347 U.S. 507 (1954).
} 
tion. ${ }^{255}$ But where such claims represent the kind of injury courts conventionally recognize-especially physical injury, as in that casetheir magnitude simply reflects the size of the injury which large-scale and perhaps increasingly dangerous ${ }^{256}$ activity by government may inflict on its citizens. It would change the essential picture only when the liability was so crushing that it reflected wholesale destruction of the social wealth in a way that would spell a breakdown for any system of liability. ${ }^{257}$ After all, England socialized the losses from German bombings during the last war, ${ }^{258}$ and we were prepared to do the same. $^{259}$

A deeper question is whether government liability should be limited by the fault principle. If Miller's healthy horse is killed because a board of health mistakenly thinks it is diseased, ${ }^{260}$ why should Miller's compensation by the community depend on whether or not the mistake was reasonable? His injury is the same in either event and is a more or less inevitable result (given the likelihood of human failings) of activity carried on for the community's benefit. There is perhaps increasing recognition of a principle which would make this a basis of enterprise liability, ${ }^{261}$ without any regard to fault. Such a principle has found expression in constitutional guaranties of compensation where there is an exercise of eminent domain, ${ }^{262}$ and in workmen's compensa-

${ }^{255}$ Dalehite v. United States, 346 U.S. 15 (1953).

${ }^{258}$ Consider the possibilities opened up by the prospect of continued development of atomic weapons.

${ }^{257}$ In other cases the language of Lord Holt is apt: "But it is objected, that there will be a multiplication of actions. I answer, so there ought; for if one will multiply injuries, it is fit the actions for the same should be multiplied. . .." Ashby v. White, 6 Mod. 45 , 54 (K.B., 1703).

${ }^{258}$ See Report by Prime Minister Churchill to Parliament on the Progress of the War, October 9, 1940 [as reported in N.Y. Times $\$ 1$, p. 4, col. 4 (Oct. 9, 1940)], quoted in Shulman and James, op. cit. supra n. 253, at 59-60.

Compare also the Fort of the Double-Crown case wherein the French Conseil d'Etat awarded damages to those injured by the explosion of a large ammunition dump on the outskirts of Paris during the First World War. Consult Schwartz, Public Tort Liability in France, 29 N.Y.U.L. Rev. 1432, 1434 et seq. (1954).

${ }^{250} 56$ Stat. 175,176 (1942), 15 U.S.C.A. 606b-1, 606b-2, 609 q. (1948) (act providing for damage insurance).

${ }^{260}$ See note 162 supra. Cf. Schwartz 274 ; note 261 infra (compensation for the convicted innocent).

${ }^{201}$ See authorities cited in note 1 supra; consult also Leflar, Negligence in Name Only, 27 N.Y.U.L. Rev. 564 (1952); Feezer, A Circle Tour through Negligence, ibid., at 647. One situation in which the risk theory ought to be, and occasionally is, recognized is that where compensation is sought for the death or imprisonment of innocent persons mistakenly convicted of crime. Consult Borchard, State Indemnity for Errors of Criminal Justice, 21 B.U.L. Rev. 201 (1941); Street 44.

${ }^{262}$ For the influence of the eminent domain principle on the development of a risk theory in French droit administratif, see Schwartz 269 et seq. 
tion statutes. It has also a long tradition of recognition in our common law-a tradition far older indeed than the recognition of negligence as a tort. ${ }^{263}$ Ultimately all governmental liability may be put on some such basis-there is apparently a distinct tendency in this direction in France, ${ }^{264}$ and most of our own governmental employees are covered by workmen's compensation. ${ }^{265}$ But any over-all adoption of such a risk theory of liability is probably unlikely in the foreseeable future in this country. This is just as true in the field of government as of private enterprise. On the other hand, where that theory has already found expression in rules of strict liability for private enterprise, there seems to be no justification whatever for exempting government from the same rules.

If the foregoing analysis is accepted, it reveals serious basic shortcomings in the Federal Tort Claims Act: That act should certainly not exclude strict or risk liability where such liability is already ensconced in our general tort law. It should certainly not exclude liability for deliberate torts. As to liability for discretionary acts, the second provision of Section 2680 (a) may have been meant to embody only a legitimate exception and possibly it might have been so interpreted though its language invited a much broader-and quite indefensiblescope for immunity, ${ }^{266}$ and unfortunately the courts have accepted the invitation. Since the millstone of this interpretation is now hung around its neck, and since it is not needed for the only purpose it should serve, this provision should be repealed. The first provision of this section (providing immunity for acts carefully done pursuant to statute or regulation even if invalid) poses a much closer question. Government fault in such a case is rather hard to see, unless one were to take a somewhat doctrinaire view of governmental actions beyond what a court later decides were the limits of legislative or executive power. The question here is really whether we wish to extend the risk theory this far.

${ }^{203}$ Consult, e.g., Wigmore, Responsibility for Tortious Acts, 7 Harv. L. Rev. 315, 383, 441 (1894) ; Winfield, History of Negligence in the Law of Torts, 42 L. Q. Rev. 184 (1926); 1 Street, Foundations of Legal Liability c. 6 (1906); 8 Holdsworth 446-59; 3 ibid., at 375 et seq.

schwartz 269 et seq.; Street 18, 76. Schwartz, Public Tort Liability in France, 29 N.Y.U.L. Rev. 1432 (1954). Consult also Gellhorn and Lauer, Federal Liability for Personal and Property Damage, 29 N.Y.U.L. Rev. 1325, 1335-36 (1954) (suggesting some tendency in this direction in the congressional handling of claims).

${ }^{200} 1$ Larson, Workmen's Compensation Law $\$ 56$ (1952).

${ }^{200}$ See dissenting opinion of Jackson, J., in Dalehite v. United States, 346 U.S. 15 (1953). 